Can a Higher Wage Attract Better-Quality Applicants Without Deteriorating Public Service Motivation? Evidence from the Bangladesh Civil Service

Md. Rajibul Alam

Yoko Kijima

February 2020

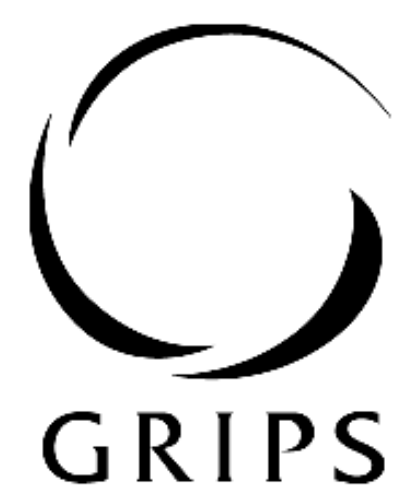

National Graduate institute FOR POLICY STUDIES

National Graduate Institute for Policy Studies

7-22-1 Roppongi, Minato-ku,

Tokyo, Japan 106-8677 


\title{
Can a Higher Wage Attract Better-Quality Applicants Without Deteriorating Public Service Motivation? Evidence from the Bangladesh Civil Service
}

\author{
Md. Rajibul Alam ${ }^{\text {a }}$ and Yoko Kijima ${ }^{\text {a* }}$

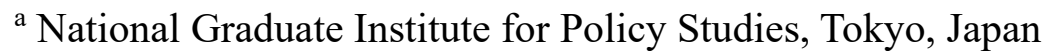

\begin{abstract}
Although the civil service plays a critical role in economic development, it performs poorly in many countries, partly due to civil servants' low salaries. Therefore, in 2015, the Bangladesh government doubled the salary of civil servants. However, the reform may worsen public service delivery by attracting those who have lower public service motivation (PSM). Using the data of applicants to the Bangladesh civil service (BCS), this study examines the effect of the 2015 pay-scale reform on PSM. Taking a difference-in-differences approach, this study finds that the BCS officers hired after the reform are both academically smarter and more motivated to public service than those hired before the reform. Our results suggest that salary increases can be an effective for recruiting higher-quality officers.
\end{abstract}

Keywords: Public service motivation, Pro-Social behavior, Civil service, Wage, Salaries, Applicants, Pay scale reform, Bangladesh

JEL classification: H1, H83, D73, J310, O20

Address: 7-22-1 Roppongi, Minato-ku, Tokyo 106-8677, Japan

E-mail:kijima@grips.ac.jp 


\section{Introduction}

A competent civil service, as a core element of state capacity, is essential for the efficient provision of public services and key to reducing poverty in developing countries (Rose-Ackerman \& Palifka, 2016). However, the civil service in many developing countries is characterized by low productivity (Nunberg \& Nellis, 1990; Shepherd, 2003). It is widely recognized that lower compensation in the public sector is one of the main reasons for this low productivity (Delfgaauw \& Dur, 2010; Finan, Olken, \& Pande, 2017). Therefore, offering greater financial incentives can be an effective policy instrument to motivate those who were already hired and/or to recruit higher-quality candidates for public sector jobs (De Ree, Muralidharan, Pradhan, \& Rogers, 2018). Unlike private-sector jobs, however, it is often the case that the performance of civil servants is difficult to measure objectively. ${ }^{1}$ This is why public sector does not normally adopt performance-based payment and instead tries to recruit people who are willing to work hard without financial incentives (Prendergast, 2007).

This desire to work unselfishly in the public sector is known as Public Service Motivation (PSM) (Perry, 1996). It is found that those with high PSM strongly aspire to join the public sector to serve the community (Delfgaauw \& Dur, 2008; Francois, 2000). PSM is, therefore, an important predictor for productivity and service delivery in the public sector (Perry \& Vandenabeele, 2015). However, whether higher wages attract workers with lower PSM to civil service depends on the correlation between PSM and productivity (Barigozzi, Burani, \& Raggi, 2018). If these are positively (negatively) correlated, financial incentives attract (screen out) individuals with not only high quality but also high PSM. Therefore, it is possible that offering a higher wage can screen out those with high PSM from civil service

\footnotetext{
${ }^{1}$ Empirical studies examining the effect of financial incentive on performance in public sector jobs are limited to frontline service providers such as school teachers (de Ree et al. 2018; Duflo et al. 2012) and community health providers (Ashraf et al. 2016; Banerjee et al. 2008).
} 
jobs.

The existing empirical literature examining the effect of financial incentive on recruitment shows mixed results and is limited to the case community agents, not higher-level officers. With respect to positive effects, Dal Bo, Finan, \& Rossi (2013) find that higher wages attract individuals with higher pro-social motivation for community development agent positions in marginalized municipalities in Mexico. ${ }^{2}$ For negative effects, Deserrano (2019) finds that higher financial incentives attract more applicants but crowd out the most socially motivated people from community health promoter positions in Uganda. Based on a lab-in-the-field experiment with college students in Indonesia, Banuri and Keefer (2016) find that once a higher salary is offered, students with lower PSM are more likely to choose to join the public sector. ${ }^{3}$ Thus, in the recruitment for civil service positions with high promotion prospects, there have been no rigorous empirical studies thus far that examine whether higher financial incentives screen out those with higher PSM.

This study examines the role of financial incentives in recruiting Bangladesh civil service (BCS) officers. BCS plays a key role in preparing policy and executing, supervising, and monitoring the tasks of the government (Zafarullah, 2003). However, the performance of BCS has not been satisfactory. According to World Bank governance indicators, the efficiency of BCS is low and declining (Khan, 2015). This is believed to be because the quality of the civil servants is not high, particularly due to a low salary (Jahan \& Sahan, 2012). In July 2015, the Bangladesh government doubled the civil service pay scales

${ }^{2}$ In a closely related study, Ashraf, Bandiera, and Lee (2018) find that, in the recruitment of community health workers in Zambia, career incentives to ascend the civil-service career ladder to better-paid positions help the public sector to attract candidates with higher PSM.

${ }^{3}$ Using a lab experiment on Indian college students, Hanna and Wang (2017) find that those who cheat on a dice task and those with lower pro-social preferences are more likely to prefer entering government service after graduation, regardless of cognitive ability. 
(Rhaman \& Al-Hasan, 2018), ${ }^{4}$ after which the number of applicants increased dramatically (Hossain, 2019a; Islam, 2019).

This paper contributes to the literature by answering the question if the financial incentive attracts people with higher educational achievement but lower PSM to the public sector. Using the reform as a natural experiment, this study estimates the impact of the higher wage on the qualifications and the motivational profiles of BCS applicants and incumbent officers. It is based on the data collected by face-to-face interviews with applicants who took the BCS examination before the reform and those who took it after. The estimation results show that BCS officers who were hired after the reform are better, both in academic records and PSM, than those before the reform.

This study contributes to the broader literature on labor economics and on public sector personnel economics, which investigates the effect of higher wages on recruitment (Dal Bo et al., 2013; Deserranno, 2019; Ashraf et al., 2018). To the best of the authors' knowledge, no other study has investigated the effect of a national-level pay-scale increase on the applicant pool of the civil service in developing countries. This study provides new evidence regarding the effect of the national-level compensation policy on the type of civil service applicants. ${ }^{5}$

${ }^{4}$ Just before the pay-scale reform, the average monthly wage was 17,969 BDT (\$ 225) in the private sector and 22,040 BDT (\$ 276) in the public sector. The wage differential between public and private wage increased from 10.6 percent in 2013 to 22.7 percent in 2015 (Rahman and Al-Hasan, 2018).

5 There are empirical studies examining the performance of civil service officers in developing countries. Bertrand et al. (2018) find that the Indian Administrative service (IAS) officers entering the civil service at a later age have lower promotion prospects, which results in lower performance as measured by stakeholders' evaluation and suspension records. Rasul and Rogger (2018), examining the Nigerian civil service, show that offices' use of more management practices on performance incentives is negatively correlated with the performance measure of the development projects' completion rate. 
Following this introduction, this paper presents the institutional background of BCS and the pay scale reforms in the next section. The section that follows explains the conceptual framework and postulate hypotheses. The data and characteristics of the sample are presented in the next section, and the empirical methods and estimation results are discussed thereafter. The final section presents the summary and conclusions.

\section{Institutional Background of Bangladesh Civil Service (BCS) and Pay Scale Reforms}

BCS is vertically divided into four classes (Class I to IV). Class-I officers conduct managerial and professional activities and are further divided into two categories: BCS cadre officers and Non-BCS gazette officers. In general, promotion prospects are higher for BCS cadre officers than for non-BCS gazette officers (Khan, 2015; Ferdous, 2015). BCS is vertically divided into 28 service cadres. The 28 cadres are divided into two main categories: managerial (general) cadres and technical cadres (Islam, 2016; Khan, 2015; Kim \& Monem, 2009). Civil service officers' status and ranking are set by the grades (20 is the lowest and 1 is the highest).

The recruitment of civil service officers is managed and administered by the Bangladesh Public Service Commission (BPSC), an independent constitutional body. All ministries apprise BPSC of their vacant posts through the Ministry of Public Administration. The civil service examination consists of (1) preliminary examination, (2) the written examination, and (3) the viva voce examination ${ }^{6}$ (Jahan, 2012 \& Ministry of Public

\footnotetext{
${ }^{6}$ BPSC members chair the viva board, which consists of a psychologist from a recognized university and higher government officials from a ministry nominated by the Ministry of Public Administration (Khan, 2015). The viva board members assess the candidates based on their intellectuality, emotional stability, smartness, leadership attributes, and involvement in other activities, such as sports, debate competitions, and hobbies. In 2013, the number of applicants
} 
Administration, 2014). Until 2018, 56\% of the positions were allocated according to quota provisions for privileged groups such as freedom fighters' descendants, women, people from backward districts and indigenous communities, and physically challenged individuals (Khan, 2015).

After the independence of Bangladesh, the government made several attempts to increase the civil servant pay-scales to align the salary with the cost of living. However, since the inflation rate was higher than the pay increases, the benefit from the increased pay eroded within a few months (Islam, 2016; Khan, 2015). In July 2015, the government reformed the civil servant pay structures, which was the first time this was done based on inflation and living costs. Previously, most applicants came from the arts and humanities, whereas after the 2015 pay scale reform, students from other departments, especially engineering, have begun to apply for civil service jobs (Azad, 2018; Mujumdar, 2017).

\section{Conceptual Framework and Hypotheses}

The research question of this paper is if the financial incentive attracts people with higher educational achievement but lower PSM to the public sector. Roy's (1951) model shows that candidates select a job if his/her expected return from the job is higher than the reservation wage. The expected return depends on the skills needed for a particular job and expected wage from the job. The expected returns include utility gains and satisfaction from the job. Therefore, even for the same job, the expected returns can differ based on the preference of job characteristics. Those who have higher PSM are expected to have higher satisfaction from public rather than the private sector jobs in a given wage. When the public sector wage was lower than that in private sector, those with high PSM and low reservation wage tend to apply

for the BCS exam was 221,575, of which 9,515 passed the written exam and 2,175 were selected for appointment. In 2015, 244,107 people applied for the BCS exam; 6,088 of them passed the written exam and 2,158 were selected for appointment (BPSC, 2015). 
for the public sector jobs.

Since the 2015 reform drastically increased salaries in the public sector compared with the private sector, it can equally attract people with high PSM and high reservation wage and those with low PSM and high reservation wage. As long as the number of higher-qualified candidates with high PSM increases and the selection committee can detect candidates with low PSM, the quality of civil service officers is expected to improve after the reform without sacrificing PSM.

\section{Data and Empirical method}

\subsection{Data and sample}

From 2012 to 2015 , the BPSC invited applications for the $33^{\text {rd }}, 34^{\text {th }}$, and $35^{\text {th }}$ BCS examinations (advertised in February 2012, February 2013, and September, 2014, respectively). The news about the pay scale reform that the government for civil servants had already been released before the advertisement of the $35^{\text {th }}$ BCS examination, ${ }^{7}$ and thus, its applicants are considered as the post-reform cohort. Those who took the $33^{\text {rd }}$ and $34^{\text {th }}$ BCS examinations were pre-reform cohorts.

Data from both BCS personnel and the applicants who did not pass the BCS examination were collected by the authors. The survey was conducted from October 15 to December 20, 2017. As the information on the applicants for civil service examination is confidential, it was not possible to acquire a complete list of applicants. Therefore, to prepare a nationally representative sample, data were collected from three groups: (1) 303 junior-level BCS (administration cadre) officers who applied for the BCS examinations in

\footnotetext{
7 The news of the 2015 pay scale reform was published in August 2014 (Daily Nation, 2014). There was an analysis of the pay scales by the leading think tank of Bangladesh on September 8, 2014 (Centre for Policy Dialogue, 2015).
} 
2012, 2013, and 2015; this sample size is the $40 \%$ of the total BCS (Administration cadre) officers $^{8}$ (2) 108 applicants who attended a coaching center and applied for the BCS examinations held in 2012, 2013, and/or 2015, but did not pass; and, (3) 22 friends of group (1) above, who took the BCS examination in 2012, 2013, and/or 2015 but did not pass.

For the results to be nationally representative, data were collected from 32 districts covering all eight divisions of Bangladesh. ${ }^{9}$ Based on the number of officers in the district office, 8 to 15 BCS officers from each office were randomly sampled, to obtain a total of 303 . Of these, the number of officers who took the examination in 2012, 2013, and 2015 was 90, 98, and 115, respectively. Interviewers were properly trained to explain the purpose of the study and the confidentiality of responses to the participants, so that they would be willing to provide honest answers to the questions. The interviews were conducted individually and separately.

The list of applicants who took the examination in 2012, 2013, and 2015 was collected from an established coaching center $^{10}$ in Dhaka. From the list, 108 individuals were randomly selected. The interviews normally took place at the respondent's home or office, as requested by the respondent. The BCS officers in the sample were first interviewed and the list of their friends' names and cellphone numbers was collected by asking whether they have

${ }^{8}$ In the BCS (Administration cadre), the number of officers recruited are 290, 279, and 280 in 2012, 2013, and 2015, respectively (BPSC, 2015). Only BCS (administration cadre) officers are selected as our sample. This is because there are few officers recruited for other cadre services in 2012, 2013, and 2015.

${ }^{9}$ Based on the number of districts within the division, 2 to 5 district offices from each division were randomly selected.

${ }^{10}$ In Bangladesh, there are a few coaching centers that offer intensive programs for the preparation of BCS exam. Generally, after graduation, a good number of applicants take the BCS examination after preparation via a coaching center. The coaching centers are few, and mostly located in Dhaka. Anyone can enroll in the coaching centers by paying around $\$ 125$. The course duration is 1-6 months (most commonly 3 months) for preliminary, written, and viva voce examinations. 
friends who applied for the BCS examination in the same year but did not pass. Thereafter, 22 individuals were selected from the list.

\subsection{Measures of qualities}

To measure the raw qualities of the civil service applicants, both their cognitive and non-cognitive abilities were assessed. The cognitive abilities were measured by the highest grade $(\mathrm{A}+)$ on their Secondary School Certificate (SSC) examination and whether he/she is a graduate from an engineering university/department. The SSC examination is a centralized public examination held after 10 years of schooling (NUFFIC, 2012). In Bangladesh, those who apply to engineering university need to receive at least $90 \%$ marks both in the secondary and higher secondary public exams. Whether one studies in the engineering department is a good proxy of a good academic record. The monthly real gross income in the previous job is also used as a measure of work-related skills as a high grade in school does not guarantee that one has higher productivity in the workplace. As a measure of non-cognitive ability, the Big-Five Personality Traits are used to capture different dimensions of the sampled individuals' personalities, which are necessary to perform effectively in the workplace.

Public Service Motivation (PSM) is considered to be an important characteristic for public-sector workers to provide public services effectively (Perry \& Wise, 2005; Francois, 2000; Kwon, 2012; Naff \& Crum, 1999). PSM is measured through Perry's (1996) PSM scale. Since PSM is closely related to pro-social behavior and social preferences, the pro-social behavior and the social preferences of the applicants are used in the analyses. For measuring pro-social behavior, the applicants are asked whether they participated in either volunteer or charity activities before applying for the civil service examination. By using non-incentivized hypothetical questions, social preference measures such as patience, 
risk-aversion, and altruism are elicited. ${ }^{11}$

\subsection{Descriptive Statistics}

This section presents the average characteristics of the civil service applicants and incumbent civil service officers who applied for the BCS examination before and after the pay scale reform (pre- and post-reform cohorts). Panel A consists of socio-demographic and parental characteristics while Panel B shows educational background. Panel C indicates variables related with personality traits. The first two columns of Table 1 show the average characteristics of applicants who took the exam before and after the reform. The third column shows the results of the t-test (p-value) if the mean characteristics are statistically different between these two groups. The fourth and fifth columns indicate the mean characteristics of BCS officers who took the exam before and after the reform, respectively. The last column indicates whether the means of these two groups are different.

The first three columns of Table 1 show that applicants who took the exam after the reform are less likely to be married, to have quota privilege, and to have experience in working in the private sector, and are more likely to have a father who owns a business, to obtain the highest grade in the SSC exam, and to have attended school in an urban area than applicants who took exam before the reform. According to the last three columns, BCS officers who took the exam after the reform are less likely to be married or agreeable, and are more likely to have the highest grade in SSC, to study engineering, and to have had a higher income in the previous job. In terms of parental education and labor-force participation, there is no difference between the post-reform and pre-reform cohorts. As shown in Panel C, there are no significant differences in personality traits of pre- and post-reform cohorts both in applicant pool and BCS officers.

${ }^{11}$ See appendix for how the Big-Five index, PSM, pro-social behavior, and pro-social preference are measured. 
Table 2 presents the PSM (Panel A), pro-social behaviors (Panel B), and social preferences (Panel C). Regarding the applicant pool, there is no difference in PSM index between pre-and post-reform cohorts. Among civil service officers, however, the post-reform cohort has higher PSM than the pre-reform cohort. On average, pro-social behaviors of preand post-reform cohorts are comparable in both the applicant pool and among BCS officers. Panel C suggests mixed results. While applicants in the post-reform cohort tend to have worse social preferences than those in the pre-reform cohort, BCS officers in the post-reform cohort tend to be more patient and more altruistic to the poor than those in the pre-reform cohort, which are desirable characteristics for public servants.

\section{Estimation Models and Results}

The descriptive statistics showed that both in the applicant pool and among BCS officers, educational qualification measured by the SSC exam improved on average after the reform. In terms of PSM, there is no difference between the pre and post cohorts in the applicant pool, while the PSM of BCS officers after the reform is higher than in those before. It was also found that BCS officers who took the exam after the reform tend to have better social preferences than those before the reform. In this section, regression analyses are conducted to test if even after controlling for other characteristics, BCS officers after the reform are more motivated than those before the reform.

\subsection{Estimation Model}

The effect of financial incentive on the qualities and motivational profiles of the BCS applicant pool is estimated by the following Ordinary Least Square models, similar to those of Dal Bo et al. (2013), Deserranno (2019), and Donato et al. (2017):

$$
Y_{i t}=\alpha+\beta \text { Post }_{t}+\rho X_{i t}+e_{i t} \quad \ldots \ldots \ldots \ldots \ldots \text {....... } 1
$$


where $Y_{i t}$ is educational quality (highest grade in the SSC examination or engineering graduate), the income at the previous job, personality traits, PSM, pro-social behavior, or social preferences. Post $t_{t}$ takes the value 0 if individual $i$ took the BCS examination before the 2015 pay scale reform and 1 otherwise. $\mathrm{X}$ is a set of the individual $i$ 's characteristics, determined before he or she took the SSC examination, including age, sex, location of childhood (whether raised in an urban area), schooling years, and occupation of parents. While $\alpha, \beta$, and $\rho$ are coefficients to be estimated, $e$ is an error term.

The effect of the pay-scale reform on the applicant pool is estimated by $\beta$. This is because those who took the examination in 2012 and 2013 did not know that the pay scale would increase in 2015 and thus could not have intentionally postponed their application until 2015. Further, the increased pay scale is applied to all officers, not only to those in the post-reform cohort. There is no incentive to manipulate the timing of one's application. Since BCS officers were over-sampled, sampling weights are applied in all the analyses to represent the applicant pool accurately. The standard errors are clustered at the survey location (districts and training centers where interviews were conducted) and by interviewer.

The effect of the reform on BCS officers' qualities and motivation profiles is estimated by the difference-in-difference (DID) approach:

$$
Y_{i t}=\alpha+\beta \text { Post }_{t}+\text { bPost }_{t} \times O_{i}+c O_{i}+\rho X_{i t}+e_{i t} \ldots \ldots \ldots \text {...eq. } 2
$$

where $O_{i}$ takes the value 1 if the individual passed the examination (i.e., is a BCS officer) and 0 otherwise. While $\alpha, \beta, b, c$, and $\rho$ are coefficients to be estimated, $e$ is an error term. If officers in the post-reform cohort have lower PSM (motivational profiles) on average, the coefficient of the interaction term, $b$, will be negative.

For identifying DID estimates, the common trend assumption must hold. Officers are of better academic quality than those who did not pass the examination, based on the fact that 
they passed the examination. The pre-reform trend (2012-2013) in quality should be comparable for officers and non-officers, since there is no change in the labor market situation, educational policies (ADB \& ILO, 2016; Hossain \& Mohammad, 2015; Khan et al., 2014), or recruitment criteria of the civil service officers. It is tested whether the coefficient of an interaction term between the 2013 group and those who passed the examination (officers) is significantly different from zero by using the sample of those who took the examination either in 2012 or 2013. Both for the SSC examination grade and PSM index, the coefficients are not significant, suggesting that the common trend assumption is not violated.

\subsection{Estimation Results on Applicant Pool}

Table 3 shows the estimated coefficients of Post in Equation 1 for all the qualities and motivation profiles. In 18 out of 21 models, there is no evidence that the pay-scale reform affected the characteristics of the applicant pool. The results show that the higher wage attracted people who are more pro-social, less present-biased, and less risk-averse than those in the pre-reform cohort. These results are not expected but these characteristics are preferable for BCS officers.

To summarize, there is no evidence that the higher wage attracted applicants with higher quality and with lower motivational profiles. Rather, applicants in the post-reform cohort tend to be more engaged in volunteer and charity work, less present-biased, and less risk averse. More specifically, the effect of the 2015 pay-scale reform on the civil service applicant pool is not significant on average. The more important question is whether the reform changed the quality of BCS officers or not, which is discussed in the next section.

\subsection{Effect of the reform on BCS officers}

Table 4 shows the estimated results on characteristics of BCS officers. As seen in the positive 
coefficient of Post ${ }_{t} \times O_{i}$, BCS officers recruited after the pay-scale reform have higher SSC examination scores and an engineering background. Furthermore, BCS officers in the post-reform cohort have higher PSM index, particularly committed to public service, than those in the pre-reform cohort. The results on pro-social behavior and social preference show that BCS officers who applied for the examination after the reform tend to be more patient and altruistic to the poor. Regarding the personality traits, it is found that BCS officers recruited after the reform are less extraverted and more conscientious. These traits are well suited to being a BCS officer.

In sum, BCS officers who joined the civil service after the pay scale reform have higher educational qualification, higher PSM, and better social preferences (patience and altruism) than those who joined before. Although there is no impact on the applicant pool on average, the increased number of applications from highly qualified individuals resulted in an improvement in the characteristics of BCS officers hired after the reform.

\section{Conclusions}

This study empirically examined whether financial incentives can be used as a policy instrument to recruit high-quality civil-service officers with high public-sector motivations by using the case of the 2015 pay scale reform in Bangladesh, which doubled the salaries of civil servants. Unlike the existing studies, this study examines the effectiveness of financial incentives on recruiting elite civil service officers. This is a main contribution of this study to the literature. The empirical results are encouraging: post-reform BCS officers have higher educational quality than pre-reform officers and higher PSM. Compared to pre-reform BCS officers, they are also more motivated to public service, more altruistic to the poor, and have higher social preferences. The results for the applicant pool show that applicants in the post-reform cohort are more engaged in volunteer and charity activities, less present biased, 
and less risk averse than applicants in the pre-reform cohort. Although Dal Bo et al. (2013) found that financial incentive improved the educational qualification of the applicant pool by examining frontline public sector workers, there is no evidence that financial incentive can improve educational quality of applicant pool for elite civil service jobs examined in this study.

Since the performance of the work done by BCS officers is difficult to measure, this study did not examine the effect of the reform on the performance of the civil service per se. There is no guarantee that better quality individuals at the recruitment stage continuously perform in the long run, as Bertrand et al. (2018) find in the context of the Indian elite civil service, where those with lower promotion prospects are less motivated and inefficient in providing public service. As the promotion prospect in BCS is highly politicized and $84 \%$ of our sampled BCS officers expressed concerns about promotion, the government may need to introduce promotion criteria not based on lobbying and political choices. This can motivate officers to provide public service until retirement. This can also have a positive effect on recruiting better-quality individuals for the civil service, as also found in Morgan et al. (2012).Whether the performance of BCS has improved due to the reform and whether the effects of the reform on the applicant pool in other sectors (local government) and cadre services (such as Tax, Customs, and Foreign Affairs) are similar to those found in this study (on BCS administrative cadre) remains a topic for future research.

There can be a negative consequence of the pay scale reform. As was found in the estimation results, a larger portion of highly qualified professional graduates (engineers) are hired as a BCS general cadres jobs (administration) after the reform. As Islam (2016) rightly pointed out, it is good to build a strong and capable public sector human capital when a country is in the developing stage through incentives, but in the long run, this may hamper private sector development. Policy makers must consider this possibility in advance, so that 
the public sector wage is not too high compared with private sector jobs.

Finally, as the civil service examination is conducted by the Bangladesh Public Service Commission, the list of applicants is confidential. Therefore, the list of applicants collected from the coaching centers may not perfectly representative to the actual applicant pool. It is important to keep this in mind as a caveat of this study.

Acknowledgments: We appreciate Antony Mbithi and participants of Canadian Economic Association Conference, 2019 for comments and suggestions for this paper.

Financial support: the GRIPS Emerging State Project of the Japan Society for the Promotion of Science (JSPS KAKENHI Grant Number 25101002). 


\section{References}

ADB \& ILO. (2016). Employment and the Labor Market in Bangladesh: Overview of Trends and Challenges. ADB Briefs No. 62. Available at:

https://www.adb.org/publications/employment-and-labor-market-bangladesh-trends-c hallenges.

Ashraf, N., Bandiera, O., \& Lee, S. S. (2016). Do-gooders and gogetters: Career incentives, selection, and performance in public service delivery (No. S-89236-ZMB-X). London. Retrieved from https://scholar.harvard.edu/files/lee/files/scott_lee_do-gooders_latest

Ashraf, N., Bandiera, O., \& Lee, S. S. (2018). Losing Prosociality in the Quest for Talent? Sorting, Selection, and Productivity in the Delivery of Public Service (LSE Library, 2018. No. No.88175). Retrieved from http://eprints.lse.ac.uk/id/eprint/88175

Azad, A. K. (2018, April 22). Why first target is BCS for searching Jobs in Bangladesh. BBC Bangla, pp. 1-6. Dhaka. Retrieved from www.bbc.com/bengali/news-40902334

BBS (Bangladesh Bureau of Statistics). (2016). Statistical Pocket Book Bangladesh 2015.

Dhaka: RDP section, BBS, Tejgoan, Dhaka. Retrieved from www.bbs.gov.bd

Banerjee, A. V., Glennerster, R., \& Duflo, E. (2008). Putting a Band-Aid on a corpse:

Incentives for nurses in the Indian public health care system. Journal of European Economic Association 6(2-3): 487-500. doi: 10.1162/JEEA.2008.6.2-3.487

Banuri, S., \& Keefer, P. (2016). Pro-Social Motivation, Effort and the Call to Public Service. European Economic Review, 83, 139-164. https://doi.org/10.1016/j.euroecorev.2015.10.011

Barigozzi, F., Burani, N., \& Raggi, D. (2018). Productivity crowding-out in labor markets with motivated workers. Journal of Economic Behavior and Organization, 151, 199-218. https://doi.org/10.1016/j.jebo.2018.03.018

Bertrand, M., Burgess, R., Chawla, A., \& Xu, G. (2018). The Glittering Prizes : Career 
Incentives and Bureaucrat Performance (Mimeo). Retrieved from http://www.lse.ac.uk/economics/Assets/Documents/personal-pages/robin-burgess/costsof-bureaucratic-rigidity.pdf

BPSC. (2015). Annual Report 2015. Dhaka. Retrieved from www.bpsc.gov.bd

Centre for Policy Dialogue. (2015). Professor Mustafizur Rahman on pay raise of civil servants. Retrieved January 8, 2017, from http://cpd.org.bd/cpd-mustafizur-rahman-pay-raise-civil-servants-2015/

Daily Nation (2014). Govt Committed for Reasonable Pay Scale: FarashUddin. The Daily Nation. Dhaka. Retrieved from http://thedailynewnation.com/news/22754/govt-committed-for-reasonable-pay-scale-far ashuddin.html

Dal Bo, E., Finan, F., \& Rossi, M. (2013). Strengthening state capabilities: The role of financial incentives in the call to public service. The Quarterly Journal of Economics, 128(3), 1-50. https://doi.org/10.1093/qje/qjt008

Deserranno, E. (2019). Financial incentives as signals: experimental evidence from the recruitment of village promoters in Uganda. American Economic Journal: Applied Economics, 11(1), 277-317.

De Ree, J., Muralidharan, K., Pradhan, M., \& Rogers, H. (2018). Double for Nothing? Experimental Evidence on an Unconditional Teacher Salary Increase in Indonesia. Quarterly Journal of Economics (Forthcoming), 133(2), 993-1039.

https://doi.org/http://10.0.4.69/qje/qjx040\%0A

Delfgaauw, J., \& Dur, R. (2008). Incentives and Workers' Motivation in the Public Sector. The Economic Journal, 118(2003), 171-191. https://doi.org/10.1111/j.1468-0297.2007.02108.x

Delfgaauw, J., \& Dur, R. (2010). Managerial talent, motivation, and self-selection into public 
management. Journal of Public Economics, 94(9-10), 654-660.

https://doi.org/10.1016/j.jpubeco.2010.06.007

Donato, K., Miller, G., Mohanan, M., Truskinovsky, Y., \& Vera-Hernández, M. (2017).

Personality traits and performance contracts: Evidence from a field experiment among maternity care providers in India. American Economic Review, 107(5), 506-510.

https://doi.org/10.1257/aer.p20171105

Duflo, E., Hanna, R., \& Ryan, S. (2012). Incentives Work: Getting Teachers to Come to School. American Economic Review 102(4): 1241-1278. doi: 10.1257/aer.102.4.1241

Ferdous, J. (2015). Recruitment in Bangladesh Civil Service: Do Meritorious Get Enough Representation? South Asian Journal of Policy and Governance, 37(2), 101-113.

Finan, F., Olken, B. A., \& Pande, R. (2017). The Personnel Economics of the Developing State. In A. V. Banerjee and E. Duflo (Ed.), Handbook of Economic Field Experiments (pp. 467-514). Elsevier B.V.

Francois, P. (2000). 'Public service motivation' as an argument for government provision.

Journal of Public Economics, 78, 275-299.

https://doi.org/10.1016/S0047-2727(00)00075-X

Hanna, R., \& Wang, S. (2017). Dishonesty and selection into public service: Evidence from India. American Economic Journal: Economic Policy 9(3): 262-90. doi:

10.1257/pol.20150029

Hossain, M. (2019). What is the condtion of four BCS ? (2019, January 7). The Daily Prothom Alo. Dhaka. Retrieved from https://www.prothomalo.com/bangladesh/article/1573565

Hossain, M. M., \& Mohammad, A. M. (2015). Higher education reform in Bangladesh: An analysis. Workplace: A Journal for Academic Labor, 25(9), 64-68. https://doi.org/10.5901/mjss.2014.v5n9p423 
Islam, N. (2016). Governance for Development: Political and Administrative Reforms in Bangladesh. Springer.

Islam, S. (2017). The Government Job: Furor of Youth for BCS Job, problems remain somewhere. (2017, November 20). The Daily Prothom Alo. Dhaka. Retrieved from https://www.prothomalo.com/opinion/article/1369506.

Jahan, F., \& Sahan, M. (2012). Bureau Bashing and Public Service Motivation : A Case for the Civil Service of Bangladesh. International Journal of Public Administration, 35(4), 272-284. https://doi.org/10.1080/01900692.2012.651407

Jahan, M. (2012). Recruitment and Selection Process in Bangladesh Civil Service: A Critical Overview. Public Policy and Administration Research, 2(5), 29-36.

John, O. P. (1990). The 'Big Five' Factor Taxonomy: Dimensions of Personality in the Natural Language and in Questionnaires. In L. A. Pervin (Ed.), Handbook of Personality: Theory and Research (pp. 66-100). New York: Guilford Press.

Khan, A. A. (2015). Gresham's Law Syndrome and Beyond:An Analysis of the Bangladesh Bureaucracy. Dhaka: The University Press.

Khan, M. N., Rana, E., \& Haque, M. (2014). Reforming the Education System in Bangladesh: Reckoning a Knowledge-based Society. World Journal of Education, 4(4), 1-11. https://doi.org/10.5430/wje.v4n4p1

Kim, P. S., \& Monem, M. (2009). Civil Service Reform in Bangladesh : All Play but Hardly Any Work. Asia Pacific Journal of Public Administration, 31(1), 57-70. https://doi.org/10.1080/23276665.2009.10779356

Kwon, I. (2012). Motivation, discretion, and corruption. Journal of Public Administration Research and Theory, 24(3), 765-794. https://doi.org/10.1093/jopart/mus062 Ministry of Public Administration. (2014). Age, Qualification, and Examination Rules-2014. Dhaka: Rule-5 Section, MOPA. Retrieved from 
http://bpsc.portal.gov.bd/sites/default/files/files/bpsc.portal.gov.bd/law/54a5cbb5_465f_ Morgan, J., Sisak, D., \& Vardy, F. (2012). On the Merits of Meritocracy (Tinbergen Institute Discussion Paper) (Vol. 077). https://doi.org/http://dx.doi.org/10.2139/ssrn.2045954 Mujumdar, A, I. (2017). The government Job: New dimension in the BCS examination. (2017, August 21). The daily Prothom Alo, Dhaka. Retrieved from https://www.prothomalo.com/opinion/article/1296701

Naff, K. C., \& Crum, J. (1999). Working for America: Does Public Service Motivation Make a Difference? Review of Public Personnel Administration, 19(4), 5-16. ttps://doi.org/10.1177/0734371X9901900402

NUFFIC. (2012). Education system Bangladesh: Described and Compared with Dutch System. NUFFIC. Retrieved from https://www.nuffic.nl/en/publications/find-a-publication/education-system-bangladesh.pdf Nunberg, B., \& Nellis, J. (1990). Civil Service Reform and the World Bank (The PRE No. WPS-042). Washinton,DC. https://doi.org/10.1596/0-8213-2117-X

Perry, J. L. (1996). Measuring public service motivation: An assessment of construct reliability and validity. Journal of public administration research and theory, 6(1), 5-22.

Perry, J., \& Vandenabeele, W. (2015). Public Service Motivation Research: Achievements, Challenges, and Future Directions. Public Administration Review, 75(5), 692-699. https://doi.org/10.1111/puar.12430.

Perry, J. L., \& Wise, L. R. (2005). The Motivational Bases of Public Service. Public Administration Review, 65(4), 390-395. Retrieved from http://www.jstor.org/stable/976618

Prendergast, C. (2007). The motivation and bias of bureaucrats. American Economic Review, 97(1), 180-196.

Rahman, M., \& Al-Hasan, Md. (2018). Why is the relative preference for government jobs on 
the rise in Bangladesh? Evidence from labour force surveys. MPRA paper no. 90133. Munich, Germany. Retrieved from https://mpra.ub.uni-muenchen.de/id/eprint/90133

Rasul, I., \& Rogger, D. (2018). Management of Bureaucrats and Public Service Delivery: Evidence from the Nigerian Civil Service. Economic Journal, 128(608), 413-446. https://doi.org/10.1111/ecoj.12418

Rose-Ackerman, S., \& Palifka, B. J. (2016). Corruption and government: Causes, consequences, and reform. Cambridge: Cambridge University Press.

Roy, A. (1951). Some Thoughts on the Distribution of Earnings. Oxford Economic Papers, 3(2), new series, 135-146. Retrieved from http://www.jstor.org/stable/2662082 Shepherd, G. (2003). Civil Service Reform in Developing Countries : Why Is It Going Badly? In 11th International Anti-Corruption Conference (pp. 1-26). Seoul. Korea Zafarullah, H. (2003). Public Administration in Bangladesh: Political and Bureucratic Dimensions. In K. K. Tummala (Ed.), Comparative Bureaucratic System (pp. 265-288). Lanham, Maryland.: Lexington Books. 
Table 1. Socio-demographic condition, educational background, and personality traits of the applicants and incumbent civil service officers who took BCS exam before and after the 2015 Pay Scale Reform

\begin{tabular}{|c|c|c|c|c|c|c|}
\hline Variables & $\begin{array}{l}\text { Applicants } \\
\text { who took } \\
\text { BCS exam } \\
\text { before the } \\
\text { reform }\end{array}$ & $\begin{array}{l}\text { Applicants } \\
\text { took BCS } \\
\text { exam after } \\
\text { the reform }\end{array}$ & $\begin{array}{l}p \text {-valu } \\
\text { e }\end{array}$ & $\begin{array}{l}\text { Incumbent } \\
\text { BCS } \\
\text { officers who } \\
\text { took BCS } \\
\text { exam before } \\
\text { the reform }\end{array}$ & $\begin{array}{l}\text { Incumbent } \\
\text { BCS } \\
\text { officers who } \\
\text { took the } \\
\text { BCS exam } \\
\text { after the } \\
\text { reform }\end{array}$ & p-value \\
\hline \multicolumn{7}{|c|}{ Panel A: Mean Characteristics (Socio-demographic condition) } \\
\hline Number of obs. & 279 & 154 & & 188 & 115 & \\
\hline Married & $\begin{array}{c}0.60 \\
(0.49)\end{array}$ & $\begin{array}{c}0.28 \\
(0.45)\end{array}$ & 0.00 & $\begin{array}{c}0.79 \\
(0.41)\end{array}$ & $\begin{array}{c}0.46 \\
(0.50)\end{array}$ & 0.00 \\
\hline Male & $\begin{array}{c}0.80 \\
(0.40)\end{array}$ & $\begin{array}{c}0.73 \\
(0.44)\end{array}$ & 0.11 & $\begin{array}{c}0.69 \\
(0.46)\end{array}$ & $\begin{array}{c}0.68 \\
(0.47)\end{array}$ & 0.84 \\
\hline Raised in urban area & $\begin{array}{c}0.58 \\
(0.49)\end{array}$ & $\begin{array}{c}0.64 \\
(0.48)\end{array}$ & 0.23 & $\begin{array}{c}0.74 \\
(0.44)\end{array}$ & $\begin{array}{c}0.70 \\
(0.46)\end{array}$ & 0.48 \\
\hline $\begin{array}{l}\text { Schooling years of } \\
\text { father }\end{array}$ & $\begin{array}{l}12.25 \\
(4.08)\end{array}$ & $\begin{array}{l}12.38 \\
(3.34)\end{array}$ & 0.72 & $\begin{array}{c}13.3 \\
(3.96)\end{array}$ & $\begin{array}{c}13.4 \\
(3.39)\end{array}$ & 0.82 \\
\hline Father does business & $\begin{array}{c}0.21 \\
(0.41)\end{array}$ & $\begin{array}{c}0.37 \\
(0.48)\end{array}$ & 0.00 & $\begin{array}{c}0.17 \\
(0.38)\end{array}$ & $\begin{array}{c}0.24 \\
(0.43)\end{array}$ & 0.13 \\
\hline $\begin{array}{l}\text { Father is } 1^{\text {st }} / 2^{\text {nd }} \text { class } \\
\text { government officer }\end{array}$ & $\begin{array}{c}0.19 \\
(0.39)\end{array}$ & $\begin{array}{c}0.26 \\
(0.44)\end{array}$ & 0.10 & $\begin{array}{c}0.27 \\
(0.44)\end{array}$ & $\begin{array}{c}0.34 \\
(0.48)\end{array}$ & 0.13 \\
\hline $\begin{array}{l}\text { Schooling years of } \\
\text { mother }\end{array}$ & $\begin{array}{c}9.52 \\
(3.39)\end{array}$ & $\begin{array}{c}9.62 \\
(2.26)\end{array}$ & 0.71 & $\begin{array}{l}10.37 \\
(3.49)\end{array}$ & $\begin{array}{l}10.93 \\
(3.46)\end{array}$ & 0.18 \\
\hline Mother has job & $\begin{array}{c}0.11 \\
(0.31)\end{array}$ & $\begin{array}{c}0.07 \\
(0.25)\end{array}$ & 0.17 & $\begin{array}{c}0.16 \\
(0.37)\end{array}$ & $\begin{array}{c}0.21 \\
(0.41)\end{array}$ & 0.32 \\
\hline $\begin{array}{l}\text { Previous Log Real } \\
\text { Income }\end{array}$ & $\begin{array}{l}10.25 \\
(0.39)\end{array}$ & $\begin{array}{l}10.24 \\
(0.45)\end{array}$ & 0.87 & $\begin{array}{l}10.21 \\
(0.43)\end{array}$ & $\begin{array}{r}10.45 \\
(0.43)\end{array}$ & 0.00 \\
\hline $\begin{array}{l}\text { Enroll in coaching } \\
\text { center }\end{array}$ & $\begin{array}{c}0.63 \\
(0.63)\end{array}$ & $\begin{array}{c}0.68 \\
(0.68)\end{array}$ & 0.36 & $\begin{array}{c}0.40 \\
(0.49)\end{array}$ & $\begin{array}{c}0.38 \\
(0.49)\end{array}$ & 0.78 \\
\hline Quota privilege & $\begin{array}{c}0.22 \\
(0.42)\end{array}$ & $\begin{array}{c}0.11 \\
(0.32)\end{array}$ & 0.00 & $\begin{array}{c}0.46 \\
(0.50)\end{array}$ & $\begin{array}{c}.50 \\
(0.50)\end{array}$ & 0.58 \\
\hline Did private sector job & $\begin{array}{c}0.33 \\
(0.47) \\
\end{array}$ & $\begin{array}{c}0.18 \\
(0.38) \\
\end{array}$ & 0.00 & $\begin{array}{c}0.34 \\
(0.48) \\
\end{array}$ & $\begin{array}{c}0.27 \\
(0.45) \\
\end{array}$ & 0.17 \\
\hline \multicolumn{7}{|c|}{ Panel B: Mean Characteristics (Educational Background) } \\
\hline $\begin{array}{l}\text { Highest Grade in SSC } \\
\text { exam }\end{array}$ & $\begin{array}{c}0.19 \\
(0.47)\end{array}$ & $\begin{array}{c}0.32 \\
(0.39)\end{array}$ & 0.00 & $\begin{array}{c}0.24 \\
(0.43)\end{array}$ & $\begin{array}{c}0.51 \\
(0.50)\end{array}$ & 0.00 \\
\hline Schooling Years & $\begin{array}{l}16.90 \\
(0.30)\end{array}$ & $\begin{array}{l}16.92 \\
(0.31)\end{array}$ & 0.38 & $\begin{array}{l}16.87 \\
(0.33)\end{array}$ & $\begin{array}{l}16.84 \\
(0.49)\end{array}$ & 0.52 \\
\hline Schooling in urban area & $\begin{array}{c}0.33 \\
(0.47)\end{array}$ & $\begin{array}{c}0.43 \\
(0.50)\end{array}$ & 0.05 & $\begin{array}{c}0.50 \\
(0.50)\end{array}$ & $\begin{array}{c}0.50 \\
(0.50)\end{array}$ & 0.88 \\
\hline Engineering graduate & $\begin{array}{c}0.07 \\
(0.26)\end{array}$ & $\begin{array}{c}0.08 \\
(0.28)\end{array}$ & 0.73 & $\begin{array}{c}0.10 \\
(0.30)\end{array}$ & $\begin{array}{c}0.28 \\
(0.45)\end{array}$ & 0.00 \\
\hline
\end{tabular}


Table 1. Socio-demographic condition, educational background, and Personality traits of the applicants and incumbent civil service officers took BCS exam before and after the 2015 Pay Scale Reform, cont.

\begin{tabular}{|c|c|c|c|c|c|c|}
\hline Variables & \begin{tabular}{l}
\multicolumn{2}{l}{ Applicants } \\
who took \\
BCS exam \\
before the \\
reform
\end{tabular} & $\begin{array}{l}\text { Applicants } \\
\text { took BCS } \\
\text { exam after } \\
\text { the reform }\end{array}$ & $\begin{array}{l}p \text {-valu } \\
\text { e }\end{array}$ & $\begin{array}{l}\text { Incumbent } \\
\text { BCS } \\
\text { officers took } \\
\text { BCS exam } \\
\text { before the } \\
\text { reform }\end{array}$ & $\begin{array}{l}\text { Incumbent } \\
\text { BCS } \\
\text { officers took } \\
\text { BCS exam } \\
\text { after the } \\
\text { reform }\end{array}$ & $p$-value \\
\hline \multicolumn{7}{|c|}{ Panel C: Mean Characteristics (Personality traits) } \\
\hline Big 5 Index & $\begin{array}{c}0.06 \\
(0.37)\end{array}$ & $\begin{array}{l}-0.00 \\
(0.37)\end{array}$ & 0.09 & $\begin{array}{c}0.09 \\
(0.43)\end{array}$ & $\begin{array}{c}0.04 \\
(0.45)\end{array}$ & 0.43 \\
\hline Extraversion & $\begin{array}{c}3.80 \\
(0.65)\end{array}$ & $\begin{array}{c}3.84 \\
(0.56)\end{array}$ & 0.54 & $\begin{array}{c}3.79 \\
(0.74)\end{array}$ & $\begin{array}{c}3.64 \\
(0.67)\end{array}$ & 0.07 \\
\hline Agreeableness & $\begin{array}{c}4.03 \\
(0.46)\end{array}$ & $\begin{array}{c}3.99 \\
(0.54)\end{array}$ & 0.37 & $\begin{array}{c}4.08 \\
(0.46)\end{array}$ & $\begin{array}{c}3.93 \\
(0.56)\end{array}$ & 0.02 \\
\hline Conscientiousness & $\begin{array}{c}3.63 \\
(0.55)\end{array}$ & $\begin{array}{c}3.54 \\
(0.65)\end{array}$ & 0.13 & $\begin{array}{c}3.59 \\
(0.62)\end{array}$ & $\begin{array}{c}3.65 \\
(0.68)\end{array}$ & 0.42 \\
\hline Neuroticism & $\begin{array}{c}2.67 \\
(0.67)\end{array}$ & $\begin{array}{c}2.69 \\
(0.66)\end{array}$ & 0.87 & $\begin{array}{c}2.67 \\
(0.77)\end{array}$ & $\begin{array}{c}2.67 \\
(0.74)\end{array}$ & 0.99 \\
\hline Openness & $\begin{array}{c}3.19 \\
(0.47)\end{array}$ & $\begin{array}{c}3.26 \\
(0.49) \\
\end{array}$ & 0.14 & $\begin{array}{c}3.22 \\
(0.55) \\
\end{array}$ & $\begin{array}{c}3.16 \\
(0.56)\end{array}$ & 0.32 \\
\hline
\end{tabular}

Note: Numbers in brackets are standard deviations. Sampling weight is used during calculation. 
Table 2. Public Service Motivation Score, Pro-Social behavior and Social Preferences of the applicants and incumbent civil service officers who took BCS exam before and after the 2015 Pay Scale Reform

\begin{tabular}{|c|c|c|c|c|c|c|}
\hline Variables & $\begin{array}{l}\text { Applicants } \\
\text { took BCS } \\
\text { exam before } \\
\text { the } 2015 \text { pay } \\
\text { scale reform }\end{array}$ & $\begin{array}{l}\text { Applicants } \\
\text { took BCS } \\
\text { exam after } \\
\text { the } 2015 \\
\text { pay scale } \\
\text { reform } \\
\text { (2) }\end{array}$ & $\begin{array}{l}p- \\
\text { value }\end{array}$ & $\begin{array}{l}\text { Incumbent } \\
\text { BCS officers } \\
\text { took BCS } \\
\text { exam before } \\
\text { the } 2015 \text { pay } \\
\text { scale } \\
\text { reform }\end{array}$ & $\begin{array}{l}\text { Incumbent } \\
\text { BCS officers } \\
\text { took BCS } \\
\text { exam after } \\
\text { the } 2015 \text { pay } \\
\text { scale } \\
\text { reform } \\
\quad(5)\end{array}$ & $\begin{array}{l}p \text { - } \\
\text { value }\end{array}$ \\
\hline \multicolumn{7}{|c|}{ Panel A: Public Service Motivation } \\
\hline Number of obs & 279 & 154 & & 188 & 115 & \\
\hline PSM Index & $\begin{array}{l}-0.17 \\
(0.45)\end{array}$ & $\begin{array}{l}-0.23 \\
(0.41)\end{array}$ & 0.14 & $\begin{array}{l}-0.21 \\
(0.51)\end{array}$ & $\begin{array}{l}-0.04 \\
(0.52)\end{array}$ & 0.02 \\
\hline $\begin{array}{l}\text { Attraction to Policy } \\
\text { Making }\end{array}$ & $\begin{array}{l}3.90 \\
(0.50)\end{array}$ & $\begin{array}{c}3.7 \\
(0.63)\end{array}$ & 0.01 & $\begin{array}{c}3.93 \\
(0.52)\end{array}$ & $\begin{array}{l}4.01 \\
(0.57)\end{array}$ & 0.23 \\
\hline $\begin{array}{l}\text { Commitment to the } \\
\text { Public Interest }\end{array}$ & $\begin{array}{l}3.79 \\
(0.52)\end{array}$ & $\begin{array}{l}3.86 \\
(0.45)\end{array}$ & 0.13 & $\begin{array}{c}3.74 \\
(0.54)\end{array}$ & $\begin{array}{l}4.03 \\
(0.56)\end{array}$ & 0.00 \\
\hline Social Justice & $\begin{array}{c}3.02 \\
(0.35)\end{array}$ & $\begin{array}{c}2.99 \\
(0.35)\end{array}$ & 0.47 & $\begin{array}{c}3.02 \\
(0.42)\end{array}$ & $\begin{array}{c}3.00 \\
(0.52)\end{array}$ & 0.65 \\
\hline Civic Duty & $\begin{array}{c}3.96 \\
(0.45)\end{array}$ & $\begin{array}{c}3.95 \\
(0.37)\end{array}$ & 0.74 & $\begin{array}{c}3.91 \\
(0.54)\end{array}$ & $\begin{array}{l}3.98 \\
(0.53)\end{array}$ & 0.26 \\
\hline Compassion & $\begin{array}{l}3.06 \\
(0.46)\end{array}$ & $\begin{array}{c}2.96 \\
(0.40)\end{array}$ & 0.02 & $\begin{array}{c}3.02 \\
(0.56)\end{array}$ & $\begin{array}{c}3.04 \\
(0.57)\end{array}$ & 0.77 \\
\hline Self-Sacrifice & $\begin{array}{c}4.00 \\
(0.42)\end{array}$ & $\begin{array}{c}4.04 \\
(0.31)\end{array}$ & 0.80 & $\begin{array}{c}4.02 \\
(0.46)\end{array}$ & $\begin{array}{c}4.11 \\
(0.59)\end{array}$ & 0.14 \\
\hline \multicolumn{7}{|c|}{ Making Panel B: Pro-social characteristics } \\
\hline $\begin{array}{l}\text { Participated in } \\
\text { volunteer activities }\end{array}$ & $\begin{array}{c}0.65 \\
(0.48)\end{array}$ & $\begin{array}{l}0.70 \\
(0.46)\end{array}$ & 0.27 & $\begin{array}{c}0.63 \\
(0.48)\end{array}$ & $\begin{array}{l}0.66 \\
(0.47)\end{array}$ & 0.59 \\
\hline \multicolumn{7}{|c|}{ Panel C: Social Preferences } \\
\hline Least patient & $\begin{array}{c}0.75 \\
(0.43)\end{array}$ & $\begin{array}{c}0.82 \\
(0.39)\end{array}$ & 0.09 & $\begin{array}{c}0.72 \\
(0.45)\end{array}$ & $\begin{array}{c}0.54 \\
(0.50)\end{array}$ & 0.03 \\
\hline Present bias & $\begin{array}{c}0.06 \\
(0.24)\end{array}$ & $\begin{array}{c}0.02 \\
(0.14)\end{array}$ & 0.02 & $\begin{array}{c}0.09 \\
(0.28)\end{array}$ & $\begin{array}{c}0.09 \\
(0.28)\end{array}$ & 0.89 \\
\hline Risk averse (Most) & $\begin{array}{c}0.70 \\
(0.46)\end{array}$ & $\begin{array}{c}0.57 \\
(0.50)\end{array}$ & 0.01 & $\begin{array}{c}0.70 \\
(0.46)\end{array}$ & $\begin{array}{c}0.60 \\
(0.49)\end{array}$ & 0.11 \\
\hline $\begin{array}{l}\text { Altruism to the poor } \\
\text { family }\end{array}$ & $\begin{array}{r}5.88 \\
(2.82) \\
\end{array}$ & $\begin{array}{c}5.42 \\
(2.63) \\
\end{array}$ & 0.09 & $\begin{array}{r}6.15 \\
(3.24) \\
\end{array}$ & $\begin{array}{l}7.26 \\
(2.83) \\
\end{array}$ & 0.00 \\
\hline
\end{tabular}

Note: Numbers in brackets are standard deviations. Sampling weight is used during calculation. 
Table 3. Effect of the 2015 Pay Scale Reform on Applicant Pool

\begin{tabular}{|c|c|c|}
\hline Outcome variables & $\begin{array}{l}\text { Coeff. of Post } \\
\text { (standard error) }\end{array}$ & $\begin{array}{c}\text { \# obs } \\
\text { R2 }\end{array}$ \\
\hline \multirow{2}{*}{$=1$ if grade of SSC exam is $\mathrm{A}^{+}$} & 0.06 & 433 \\
\hline & $(0.07)$ & 0.09 \\
\hline \multirow{2}{*}{ Engineering graduate } & 0.03 & 433 \\
\hline & $(0.02)$ & 0.12 \\
\hline \multirow[t]{2}{*}{ log real income in previous job } & -1.03 & 433 \\
\hline & (1.01) & 0.12 \\
\hline \multirow[t]{2}{*}{ Big 5 index } & -0.04 & 433 \\
\hline & $(0.05)$ & 0.03 \\
\hline \multirow[t]{2}{*}{ Extraversion } & 0.07 & 433 \\
\hline & $(0.07)$ & 0.04 \\
\hline \multirow{2}{*}{ Agreeableness } & -0.01 & 433 \\
\hline & $(0.15)$ & 0.06 \\
\hline \multirow[t]{2}{*}{ Conscientiousness } & -0.03 & 433 \\
\hline & $(0.10)$ & 0.05 \\
\hline \multirow[t]{2}{*}{ Neuroticism } & -0.05 & 433 \\
\hline & $(0.14)$ & 0.09 \\
\hline \multirow[t]{2}{*}{ Openness } & 0.03 & 433 \\
\hline & $(0.11)$ & 0.07 \\
\hline \multirow{2}{*}{ PSM index } & -0.01 & 433 \\
\hline & $(0.08)$ & 0.09 \\
\hline \multirow[t]{2}{*}{ Interested in Policy making } & -0.09 & 433 \\
\hline & $(0.13)$ & 0.13 \\
\hline \multirow[t]{2}{*}{ Commitment to pub service } & 0.09 & 433 \\
\hline & $(0.10)$ & 0.07 \\
\hline \multirow[t]{2}{*}{ Social Justice } & 0.02 & 433 \\
\hline & $(0.07)$ & 0.04 \\
\hline \multirow[t]{2}{*}{ Civic duty } & -0.04 & 433 \\
\hline & (0.09) & 0.04 \\
\hline \multirow[t]{2}{*}{ Compassion } & -0.03 & 433 \\
\hline & $(0.06)$ & 0.05 \\
\hline \multirow[t]{2}{*}{ Self-sacrifice } & -0.01 & 433 \\
\hline & $(0.05)$ & 0.07 \\
\hline \multirow{2}{*}{$=1$ if Participated voluntary/charity activities } & $0.15^{* * *}$ & 433 \\
\hline & $(0.05)$ & 0.13 \\
\hline \multirow[t]{2}{*}{$=1$ if Least Patient } & -0.02 & 433 \\
\hline & $(0.06)$ & 0.12 \\
\hline \multirow[t]{2}{*}{$=1$ if Present Bias } & $-0.07 * *$ & 433 \\
\hline & $(0.03)$ & 0.08 \\
\hline \multirow[t]{2}{*}{$=1$ if Most risk- averse } & $-0.23 * *$ & 433 \\
\hline & $(0.11)$ & 0.09 \\
\hline \multirow[t]{2}{*}{ Altruism to poor $(0-10)$} & -0.54 & 433 \\
\hline & $(0.49)$ & 0.05 \\
\hline
\end{tabular}

Notes: We clustered the standard error at the survey locations (districts and training center where interviewed were undertaken) and enumerators are reported in parentheses. $* * * \mathrm{p}<0.01, * * \mathrm{p}<0.05, *$ $\mathrm{p}<0.1$. Other controls are: age, male, urban, schooling years and occupation of father and mother. 
Table 4. Effect of the 2015 Pay Scale Reform on BCS Officers

\begin{tabular}{|c|c|c|c|c|}
\hline Outcome variables & $\begin{array}{c}\begin{array}{l}\text { Coeff. of Post x O } \\
\text { (s.e) }\end{array} \\
\end{array}$ & $\begin{array}{l}\text { Coeff. of } \\
\text { Post (s.e) } \\
\end{array}$ & $\begin{array}{c}\text { Coeff. of O } \\
\text { (s.e.) }\end{array}$ & $\begin{array}{c}\text { \# obs } \\
\text { R2 }\end{array}$ \\
\hline \multirow[t]{2}{*}{$=1$ if grade of SSC exam is $\mathrm{A}+$} & $0.17 *$ & 0.02 & 0.07 & 433 \\
\hline & $(0.09)$ & $(0.08)$ & $(0.05)$ & 0.10 \\
\hline \multirow[t]{2}{*}{ Engineering graduate } & $0.21 * * *$ & -0.02 & 0.02 & 433 \\
\hline & $(0.04)$ & $(0.02)$ & $(0.04)$ & 0.13 \\
\hline \multirow[t]{2}{*}{ log real income in previous job } & -0.11 & -0.74 & $2.41 * *$ & 433 \\
\hline & $(1.12)$ & $(1.27)$ & $(0.91)$ & 0.09 \\
\hline \multirow[t]{2}{*}{ Big 5 index } & -0.02 & -0.02 & 0.09 & 433 \\
\hline & $(0.07)$ & $(0.04)$ & $(0.08)$ & 0.03 \\
\hline \multirow[t]{2}{*}{ Extraversion } & $-0.30 * * *$ & 0.13 & 0.06 & 433 \\
\hline & $(0.11)$ & $(0.08)$ & $(0.11)$ & 0.04 \\
\hline \multirow[t]{2}{*}{ Agreeableness } & -0.19 & 0.05 & 0.05 & 433 \\
\hline & $(0.14)$ & $(0.16)$ & $(0.09)$ & 0.04 \\
\hline \multirow[t]{2}{*}{ Conscientiousness } & $0.20 *$ & -0.10 & -0.09 & 433 \\
\hline & $(0.12)$ & $(0.11)$ & $(0.09)$ & 0.04 \\
\hline \multirow[t]{2}{*}{ Neuroticism } & 0.02 & 0.02 & -0.01 & 433 \\
\hline & $(0.20)$ & $(0.18)$ & $(0.14)$ & 0.04 \\
\hline \multirow[t]{2}{*}{ Openness } & -0.21 & 0.10 & 0.11 & 433 \\
\hline & $(0.16)$ & $(0.14)$ & $(0.07)$ & 0.04 \\
\hline \multirow[t]{2}{*}{ PSM index } & $0.25 * *$ & -0.10 & 0.01 & 433 \\
\hline & $(0.10)$ & $(0.09)$ & $(0.07)$ & 0.08 \\
\hline \multirow[t]{2}{*}{ Interested in Policy making } & 0.23 & -0.19 & $0.19 *$ & 433 \\
\hline & $(0.16)$ & $(0.16)$ & $(0.11)$ & 0.15 \\
\hline \multirow[t]{2}{*}{ Commitment to public service } & $0.29 * *$ & 0.02 & -0.02 & 433 \\
\hline & $(0.11)$ & $(0.12)$ & $(0.10)$ & 0.07 \\
\hline \multirow[t]{2}{*}{ Social Justice } & -0.05 & 0.01 & 0.03 & 433 \\
\hline & $(0.10)$ & $(0.08)$ & $(0.05)$ & 0.03 \\
\hline \multirow[t]{2}{*}{ Civic duty } & 0.12 & -0.06 & $-0.11 * *$ & 433 \\
\hline & $(0.11)$ & $(0.11)$ & $(0.05)$ & 0.03 \\
\hline \multirow[t]{2}{*}{ Compassion } & 0.15 & -0.07 & -0.06 & 433 \\
\hline & $(0.11)$ & $(0.08)$ & $(0.08)$ & 0.05 \\
\hline \multirow[t]{2}{*}{ Self-sacrifice } & 0.12 & -0.06 & -0.00 & 433 \\
\hline & $(0.08)$ & $(0.06)$ & $(0.07)$ & 0.04 \\
\hline \multirow[t]{2}{*}{$=1$ if Participated voluntary $/$ charity activities } & -0.07 & $0.15 * *$ & 0.00 & 433 \\
\hline & $(0.08)$ & $(0.06)$ & $(0.09$ & 0.12 \\
\hline \multirow[t]{2}{*}{$=1$ if Least Patient } & $-0.28 * * *$ & $0.09 * *$ & 0.01 & 433 \\
\hline & $(0.09$ & $(0.04)$ & $(0.07)$ & 0.11 \\
\hline \multirow[t]{2}{*}{$=1$ if Present Bias } & 0.04 & $-0.08 *$ & 0.05 & 433 \\
\hline & $(0.05)$ & $(0.03)$ & $(0.04)$ & 0.08 \\
\hline \multirow[t]{2}{*}{$=1$ if Most risk- averse } & 0.05 & $-0.21 *$ & 0.07 & 433 \\
\hline & $(0.11)$ & $(0.11)$ & $(0.08)$ & 0.08 \\
\hline \multirow[t]{2}{*}{ Altruism to poor $(0-10)$} & $1.98 * *$ & $-1.01 *$ & 0.52 & 433 \\
\hline & $(0.67)$ & $(0.53)$ & $(0.70)$ & 0.07 \\
\hline
\end{tabular}

Notes: We clustered the standard error at the survey locations (districts and training center where interviewed were undertaken) and enumerators are reported in parentheses. $* * * \mathrm{p}<0.01, * * \mathrm{p}<0.05, *$ $\mathrm{p}<0.1$. Other controls are: age, male, urban, schooling years and occupation of father and mother. 


\section{Appendix: Variables}

- Age: Calculated from self-reported birthdate

- Male (male=1, 0 otherwise),

- Married (married=1, 0 otherwise)

- Raised in an urban area: equals 1 if the applicant raised in the district and capital area up to secondary education.

- Years of schooling: Measured by years. In the context of Bangladesh education system, completed primary school $=5$ years, completed secondary school $=10$ years, College graduate $=12$ years, university graduate $=16$ years, and post graduate $=17$ years.

- Father's education: Schooling years of father

- Mother's education: Schooling years of mother

- Father's occupation (business): equals 1 if the father of the respondent is in business.

- Father's occupation (government): equals 1 if the father is a first/second class government officer

- Mother has job: equals 1 if mother work outside the home for a wage.

- Highest grade in the Secondary School Certificate (SSC) examination: equals 1 if the individual got grade A+ $(90-100 \%$ marks $)$ in the secondary school certificate examination.

- Enrolled in coaching center: equals 1 if the applicants/officers took BCS examination preparation in the coaching center.

- Engineering major: equals 1 if the individual graduated from the engineering faculty of a technical university.

- Quota Privilege: This variable takes 1 if the applicants have quota privilege for getting BCS job and zero otherwise.

- Took BCS exam in 2013: It equals 1 if one applied for BCS exam in 2013 and zero otherwise.

- Experience in Private sector jobs: It equals 1 if the applicants/officers worked for private sector jobs before applying to the civil service examination and zero otherwise.

- The Big-Five factor model developed by John (1990) contains 44 items, which are in turn divided into five dimensions of personality: extraversion; agreeableness; consciousness; neuroticism, and openness (Almlund et al., 2011). The responses were collected on 5-point Likert scales, showing the extent to which the applicants and officers agreed or disagreed with the statements. In this study, we use a shorter list of questions containing 10 questions, with 2 questions per dimension, following Donato et al. (2017) and Rammstedt \& John (2007).

- Extraversion: Extravert represents the traits of an individual related to activity and energy, mainly sociable (Benet-Martínez \& John, 1998). Computed as the average response to the two questions related to extraversion.

I like to interact and talk with people.

I am sometime shy and unable to communicate with other easily. (reversed)

Cronbach's alpha for these two questions: 0.4 
- Agreeableness: Agreeableness represents the traits of an individual related to altruism, tender mindedness, trust and modesty (Benet-Martínez \& John, 1998). Computed as the average response to the two questions related to Agreeableness.

I like to cooperate with others although it is difficult.

I tend to find fault with others (reversed).

Cronbach's alpha for these two questions: 0.12

- Conscientiousness: Conscientiousness represents the traits of an individual related to hardworking, organized, responsible and goal directed behavior (Benet-Martínez \& John, 1998). Computed as the average response to the two questions related to extraversion.

I do any task with regard to every detail: not superficial and partial.

Anybody can depend on me (in general).

Cronbach's alpha for these two questions: 0.4

- Neuroticism: Neuroticism represents the traits of the individual related to anxiety, sadness, irritability, nervousness, emotional instability. Computed as the average response to the two questions related to Neuroticism.

I can be tensed a lot in any matter.

I am emotionally stable, not easily upset (reversed).

Cronbach's alpha for these two questions: 0.3

- Openness: Individual having openness behavior shows openness to new aesthetic, cultural and intellectual experiences (Dal Bo et al., 2013). Computed as the average response to the two questions related to Openness.

I like to think deeply or carefully about any task.

I Prefer work that is routine (reversed).

Cronbach's alpha for these two questions: 0.4

- Big-Five Personality Index: It is an equally weighted average of the z-score of each module of the Big-Five Personality inventory. In the case of Neuroticism module, we consider the reverse score as it is a negative trait.

- PSM index: To construct PSM index we elicit 12 statements from the 40 statements from Perry's 1996 scale of Public service motivation (Perry, 1996), and created an equally weighted average of the z-scores of each module of the PSM.

- Attraction to Policy Making: Computed as the average response to the following two questions.

I am interested in making public programs and policies which are beneficial for the country.

I like to share my views on public policies with others.

- Participated in volunteering or charity activities: equal 1 if the individual did voluntary works or charity activities before applying in the civil service, 0 otherwise.

- Commitment to the Public Interest: Computed as the average response to the following two questions.

An official's obligation to the public should always come before loyalty to superiors. I would prefer seeing public officials do what is best for the whole community even if it harmed my interests.

- Social Justice: Computed as the average response to the following two questions. 
I am not afraid to go to bat for the rights of others even if it means I will be ridiculed. I do not believe that government can do much to make society fairer (reversed).

- Civic Duty: Computed as the average response to the following two questions. I believe everyone has a moral commitment to civic affairs no matter how busy they are.

I have an obligation to look after those less well off.

- Compassion: Computed as the average response to the following two questions.

I have little compassion for people in need who are unwilling to take the first step to help themselves (reversed).

It is difficult for me to contain my feelings when I see people in distress.

- Self-Sacrifice: Computed as the average response to the following two questions. I believe in putting duty before self. Making a difference in society means more to me than personal achievements.

- Patience and Present Bias: To measure the patience and present bias, we asked hypothetically 4 questions. $Q 1$ : If he buys a shirt and wins a prize, he can receive the prize money $2000 \mathrm{BDT}$ instantly or $2500 \mathrm{BDT}$ after one month. Would he like to wait for one month? Yes/No. Q2: If $\mathrm{Q} 1=\mathrm{No}$, The respondent is asked if he is offered 3000 BDT after one month, would he like to wait for one month? Yes/No. Q3: If he buys a shirt and wins a prize, he can receive the prize money 2000 after one month or 2500 after two months. Would he like to wait for two months? Yes/No. Q4: If Q3=No, The respondent is asked if he is offered 3000 BDT after two months, would he like to wait for two month? Yes/No. By using the response to Q2, if one did not agree to wait for two months, we consider them "least patient". If one answered Yes in Q1 and No in Q3, or Yes in Q2 and No in Q4, they were identified as "present bias".

- Most-risk averse: To measure the risk taking behavior, the respondents were asked 3 lottery questions to choose (A) or (B): (1) (A) 2000 BDT with certainty or (B) $50 \%$ chance of winning 4000 and $50 \%$ chance of zero, (2) (A) 2000 BDT with certainty or (B) $50 \%$ chance of winning 8000 and $50 \%$ chance of zero, (3) (A) 2000 BDT with certainty or (B) $50 \%$ chance of winning 10000 and $50 \%$ chance of zero. Those who did not want to take the risk in lottery 3 are identified as the most risk-averse.

- Altruism: In this article, we define altruism as the level of the unselfishness of the respondents to a poor family. To do so, the respondent is asked a hypothetical question: if the respondent is given 10 tokens ( 1 token values $100 \mathrm{BDT}$ ), how many tokens does he want to give to poor families and how many tokens does he want to keep for himself. Those who agreed to give more tokens to poor families are considered as more altruistic.

- Price Index (CPI) of Bangladesh: CPI data were collected from World Bank (2017). We converted the previous wages of the last job to real value at the price level of 2017. BCS officers who applied for the exam in 2012, 2013, and 2014 were appointed to the first post 2.5 years later. So the income of previous job before joining to BCS was measured at price level of 2014, 2015, and 2017, respectively. CPI in 2014, 2015, and 2017 is $136.05,152.32$, and 161.14 , respectively. 
Reference

Almlund, M., Duckworth, A. L., Heckman, J., and Kautz, T. (2011). Personality Psychology and Economics. Handbook of the Economics of Education (Vol. 4). Elsevier B.V. https://doi.org/10.1016/B978-0-444-53444-6.00001-8

Alonso, P., and Lewis, G. B. (2001). Public Service Motivation and Job Performance: Evidence from the Federal Sector. The American Review of Public Administration, 31(4), 363-380. https://doi.org/10.1177/02750740122064992

Bangladesh Bureau of Statistics (BBS). (2016). Statistical Pocket Book Bangladesh 2015. Dhaka: RDP section, BBS, Tejgoan, Dhaka. Retrieved from www.bbs.gov.bd

Barrick, M. R., and Mount, M. . (1991). The big five personality dimensions and job performance. Personnel Psychology, 44, 1-26. https://doi.org/10.4102/sajip.v29i1.88

Brewer, G. A., and Selden, S. C. (2000). Why Elephants Gallop: Assessing and Predicting Organizational Performance in Federal Agencies. Journal of Public Administration Research and Theory, 10(4), 685-712.

https://doi.org/10.1093/oxfordjournals.jpart.a024287

Falk, A., Becker, A., Dohmen, T., Enke, B., Huffman, D., and Sunde, U. (2018). Global Evidence on Economic Preferences. The Quarterly Journal of Economics, 133(4), 16451692. https://doi.org/10.1093/qje/qjy013

Fletcher, J. M. (2013). The effects of personality traits on adult labor market outcomes: Evidence from siblings. Journal of Economic Behavior and Organization, 89, 122-135. https://doi.org/10.1016/j.jebo.2013.02.004

Gensowski, M. (2018). Personality, IQ, and lifetime earnings. Labour Economics, 51(May 2016), 170-183. https://doi.org/10.1016/j.labeco.2017.12.004

Gregg, P., Grout, P. A., Ratcliffe, A., Smith, S., and Windmeijer, F. (2011). How important is pro-social behaviour in the delivery of public services? Journal of Public Economics, 95(7-8), 758-766. https://doi.org/10.1016/j.jpubeco.2011.03.002

Hassan, M. S. (2015). Ensuring Effective Public Service Delivery in the Field Administration of Bangladesh to Boast up Good Governance : The Perspective of Deputy Commissioner Office. International Journal of Business and Management, 10(4), 92-112. https://doi.org/10.5539/ijbm.v10n4p92

Heineck, G., and Anger, S. (2010). The returns to cognitive abilities and personality traits in Germany. Labour Economics, 17(3), 535-546. https://doi.org/10.1016/j.labeco.2009.06.001

Rammstedt, B., and John, O. P. (2007). Measuring personality in one minute or less: A 10-item short version of the Big Five Inventory in English and German. Journal of Research in Personality, 41(1), 203-212. https://doi.org/10.1016/j.jrp.2006.02.001

Tepe, M., and Prokop, C. (2018). Are Future Bureaucrats More Risk Averse? The Effect of Studying Public Administration and PSM on Risk Preferences. Journal of Public Administration Research and Theory, 28(2), 182-196. https://doi.org/10.1093/jopart/muy007

World Bank. (2017). Consumer price index $(2010=100)$. Retrieved December 4, 2018, from https://data.worldbank.org/indicator/FP.CPI.TOTL?locations $=$ BD

World Bank. (2018). Urban Population (\% of total). Retrieved November 12, 2018, from https://data.worldbank.org/indicator 


\section{Appendix: Full Estimation Results}

Appendix Table 1. Effect of the 2015 pay scale reform on the educational qualifications, market skill, \& personality of applicant pool

\begin{tabular}{|c|c|c|c|c|c|c|c|c|c|}
\hline & $\begin{array}{c}=1 \text { if grade } \\
\text { of SSC exam } \\
\text { is } A+\end{array}$ & $\begin{array}{l}\text { Engineering } \\
\text { graduate }\end{array}$ & $\begin{array}{c}\text { log real } \\
\text { income in } \\
\text { previous job }\end{array}$ & $\begin{array}{l}\text { Big } 5 \\
\text { index }\end{array}$ & Extraversion & Agreeableness & Conscientiousness & Neuroticism & Openness \\
\hline \multirow[t]{2}{*}{ Post } & 0.06 & 0.03 & -1.03 & -0.04 & 0.03 & -0.01 & -0.03 & 0.03 & 0.03 \\
\hline & $(0.07)$ & $(0.03)$ & $(1.01)$ & $(0.04)$ & $(0.07)$ & $(0.13)$ & $(0.09)$ & $(0.14)$ & $(0.11)$ \\
\hline \multirow[t]{2}{*}{ age } & -0.02 & 0.01 & $0.49 * * *$ & 0.00 & -0.01 & 0.01 & 0.01 & 0.01 & -0.01 \\
\hline & $(0.01)$ & $(0.01)$ & $(0.18)$ & $(0.01)$ & $(0.02)$ & $(0.01)$ & $(0.01)$ & $(0.02)$ & $(0.01)$ \\
\hline \multirow[t]{2}{*}{ male } & -0.06 & $0.08 * *$ & $1.27 * *$ & 0.07 & 0.12 & -0.05 & -0.00 & -0.12 & 0.05 \\
\hline & $(0.07)$ & $(0.03)$ & $(0.57)$ & $(0.05)$ & $(0.08)$ & $(0.10)$ & $(0.08)$ & $(0.08)$ & $(0.08)$ \\
\hline \multirow[t]{2}{*}{ Raised in urban } & $0.13 * *$ & $0.10 * * *$ & $0.90 *$ & -0.03 & $-0.13^{*}$ & -0.02 & 0.06 & -0.10 & -0.05 \\
\hline & $(0.06)$ & $(0.03)$ & $(0.53)$ & $(0.04)$ & $(0.07)$ & $(0.09)$ & $(0.05)$ & $(0.06)$ & $(0.07)$ \\
\hline \multirow[t]{2}{*}{ Father's education } & -0.01 & 0.00 & 0.03 & -0.00 & -0.01 & -0.01 & -0.02 & 0.00 & 0.01 \\
\hline & $(0.01)$ & $(0.00)$ & $(0.10)$ & $(0.01)$ & $(0.01)$ & $(0.01)$ & $(0.01)$ & $(0.01)$ & $(0.01)$ \\
\hline \multirow[t]{2}{*}{ Mother's education } & 0.01 & 0.01 & 0.16 & 0.01 & 0.01 & $0.02 *$ & -0.02 & 0.02 & -0.00 \\
\hline & $(0.01)$ & $(0.01)$ & $(0.12)$ & $(0.01)$ & $(0.02)$ & $(0.01)$ & $(0.02)$ & $(0.01)$ & $(0.02)$ \\
\hline \multirow{2}{*}{$\begin{array}{l}\text { Father's occupation } \\
\text { (government) }\end{array}$} & 0.08 & 0.05 & -0.11 & -0.03 & 0.04 & -0.01 & 0.08 & -0.16 & -0.03 \\
\hline & $(0.08)$ & $(0.04)$ & $(1.03)$ & $(0.05)$ & $(0.09)$ & $(0.06)$ & $(0.06)$ & $(0.14)$ & $(0.08)$ \\
\hline \multirow{2}{*}{$\begin{array}{l}\text { Father's occupation } \\
\text { (business) }\end{array}$} & 0.06 & 0.02 & 0.29 & -0.07 & 0.07 & -0.03 & -0.08 & -0.11 & $0.10 * *$ \\
\hline & $(0.08)$ & $(0.03)$ & $(0.85)$ & $(0.06)$ & $(0.11)$ & $(0.06)$ & $(0.07)$ & $(0.12)$ & $(0.05)$ \\
\hline \multirow[t]{2}{*}{ Mother has job } & $0.19 * *$ & -0.01 & -0.24 & 0.04 & 0.08 & 0.19 & 0.21 & $-0.39 * * *$ & 0.06 \\
\hline & $(0.09)$ & $(0.06)$ & $(0.66)$ & $(0.09)$ & $(0.12)$ & $(0.12)$ & $(0.13)$ & $(0.13)$ & $(0.12)$ \\
\hline \multirow[t]{2}{*}{ Constant } & $0.67 *$ & $-0.46^{* *}$ & $-12.66 * *$ & -0.04 & $3.92 * * *$ & $3.68 * * *$ & $3.53 * * *$ & $2.53 * * *$ & $3.42 * * *$ \\
\hline & $(0.36)$ & $(0.20)$ & $(5.35)$ & $(0.32)$ & $(0.52)$ & $(0.51)$ & $(0.41)$ & $(0.64)$ & $(0.43)$ \\
\hline Observations & 433 & 433 & 433 & 433 & 433 & 433 & 433 & 433 & 433 \\
\hline R-squared & 0.09 & 0.09 & 0.12 & 0.03 & 0.03 & 0.04 & 0.03 & 0.04 & 0.03 \\
\hline
\end{tabular}

Notes: We clustered the standard error at the survey locations (districts and training center where interviewed were undertaken) and enumerators are reported in parentheses. $* * * \mathrm{p}<0.01, * * \mathrm{p}<0.05, * \mathrm{p}<0.1$. 
Appendix Table 2. Effect of the 2015 pay scale reform on the PSM, pro-social behavior, \& social preferences of applicant pool

\begin{tabular}{|c|c|c|c|c|c|c|c|c|c|c|c|c|}
\hline & $\begin{array}{l}\text { PSM } \\
\text { index }\end{array}$ & $\begin{array}{l}\text { Interested } \\
\text { in Policy } \\
\text { making }\end{array}$ & $\begin{array}{l}\text { Commitment } \\
\text { to pub } \\
\text { service }\end{array}$ & $\begin{array}{l}\text { Social } \\
\text { Justice }\end{array}$ & $\begin{array}{l}\text { Civic } \\
\text { duty }\end{array}$ & Compassion & $\begin{array}{c}\text { Self- } \\
\text { sacrifice }\end{array}$ & $\begin{array}{c}=1 \text { if } \\
\text { Participated } \\
\text { voluntary } \\
\text { and } \\
\text { charity } \\
\text { activities }\end{array}$ & $\begin{array}{c}=1 \text { if } \\
\text { Least } \\
\text { Patient }\end{array}$ & $\begin{array}{c}=1 \text { if } \\
\text { Present } \\
\text { Bias }\end{array}$ & $\begin{array}{l}=1 \text { if } \\
\text { Most } \\
\text { risk- } \\
\text { averse }\end{array}$ & $\begin{array}{c}\text { Altruism } \\
\text { to poor } \\
(0-10)\end{array}$ \\
\hline Post & $\begin{array}{l}-0.03 \\
(0.08)\end{array}$ & $\begin{array}{l}-0.14 \\
(0.13)\end{array}$ & $\begin{array}{c}0.10 \\
(0.10)\end{array}$ & $\begin{array}{l}-0.01 \\
(0.07)\end{array}$ & $\begin{array}{c}-0.01 \\
(0.09)\end{array}$ & $\begin{array}{l}-0.02 \\
(0.06)\end{array}$ & $\begin{array}{l}-0.03 \\
(0.04)\end{array}$ & $\begin{array}{l}0.13 * * \\
(0.05)\end{array}$ & $\begin{array}{c}0.01 \\
(0.06)\end{array}$ & $\begin{array}{c}-0.07^{* *} \\
(0.03)\end{array}$ & $\begin{array}{l}-0.20^{*} \\
(0.10)\end{array}$ & $\begin{array}{l}-0.50 \\
(0.53)\end{array}$ \\
\hline age & $\begin{array}{c}0.00 \\
(0.01)\end{array}$ & $\begin{array}{l}-0.01 \\
(0.02)\end{array}$ & $\begin{array}{c}0.01 \\
(0.02)\end{array}$ & $\begin{array}{l}-0.00 \\
(0.01)\end{array}$ & $\begin{array}{c}0.00 \\
(0.01)\end{array}$ & $\begin{array}{l}0.02 * \\
(0.01)\end{array}$ & $\begin{array}{l}-0.01 \\
(0.01)\end{array}$ & $\begin{array}{c}0.02 * * \\
(0.01)\end{array}$ & $\begin{array}{l}-0.02 \\
(0.01)\end{array}$ & $\begin{array}{l}-0.01 * \\
(0.01)\end{array}$ & $\begin{array}{c}-0.03 * * \\
(0.01)\end{array}$ & $\begin{array}{c}0.01 \\
(0.07)\end{array}$ \\
\hline male & $\begin{array}{c}0.17 * * * \\
(0.05)\end{array}$ & $\begin{array}{c}0.35^{* * * *} \\
(0.12)\end{array}$ & $\begin{array}{c}0.08 \\
(0.06)\end{array}$ & $\begin{array}{c}0.03 \\
(0.04)\end{array}$ & $\begin{array}{c}0.04 \\
(0.05)\end{array}$ & $\begin{array}{l}-0.02 \\
(0.05)\end{array}$ & $\begin{array}{c}0.05 \\
(0.04)\end{array}$ & $\begin{array}{c}0.35^{* * * *} \\
(0.04)\end{array}$ & $\begin{array}{l}-0.09 \\
(0.08)\end{array}$ & $\begin{array}{c}-0.04 \\
(0.04)\end{array}$ & $\begin{array}{l}-0.04 \\
(0.07)\end{array}$ & $\begin{array}{c}0.02 \\
(0.44)\end{array}$ \\
\hline Raised in urban & $\begin{array}{c}-0.11 * * * \\
(0.04)\end{array}$ & $\begin{array}{c}0.04 \\
(0.04)\end{array}$ & $\begin{array}{c}-0.15 * * * \\
(0.05)\end{array}$ & $\begin{array}{l}-0.07 * \\
(0.03)\end{array}$ & $\begin{array}{c}0.00 \\
(0.07)\end{array}$ & $\begin{array}{l}-0.07 \\
(0.05)\end{array}$ & $\begin{array}{c}-0.11 * * \\
(0.04)\end{array}$ & $\begin{array}{l}-0.01 \\
(0.07)\end{array}$ & $\begin{array}{l}-0.08^{*} \\
(0.05)\end{array}$ & $\begin{array}{c}0.01 \\
(0.02)\end{array}$ & $\begin{array}{l}-0.09 \\
(0.08)\end{array}$ & $\begin{array}{c}0.72 * * \\
(0.33)\end{array}$ \\
\hline Father's education & $\begin{array}{l}-0.01 \\
(0.01)\end{array}$ & $\begin{array}{l}-0.01 \\
(0.01)\end{array}$ & $\begin{array}{c}0.01 \\
(0.01)\end{array}$ & $\begin{array}{c}-0.01 * * \\
(0.00)\end{array}$ & $\begin{array}{l}-0.01 \\
(0.01)\end{array}$ & $\begin{array}{l}-0.01 \\
(0.01)\end{array}$ & $\begin{array}{l}-0.00 \\
(0.01)\end{array}$ & $\begin{array}{c}0.00 \\
(0.01)\end{array}$ & $\begin{array}{c}0.00 \\
(0.01)\end{array}$ & $\begin{array}{c}0.01 * * \\
(0.00)\end{array}$ & $\begin{array}{c}0.01 \\
(0.01)\end{array}$ & $\begin{array}{l}-0.03 \\
(0.05)\end{array}$ \\
\hline Mother's education & $\begin{array}{c}0.01 \\
(0.01)\end{array}$ & $\begin{array}{c}0.00 \\
(0.01)\end{array}$ & $\begin{array}{l}-0.00 \\
(0.01)\end{array}$ & $\begin{array}{c}0.01 \\
(0.01)\end{array}$ & $\begin{array}{c}0.01 \\
(0.02)\end{array}$ & $\begin{array}{c}0.00 \\
(0.01)\end{array}$ & $\begin{array}{l}-0.00 \\
(0.01)\end{array}$ & $\begin{array}{c}0.00 \\
(0.01)\end{array}$ & $\begin{array}{l}-0.02 \\
(0.01)\end{array}$ & $\begin{array}{c}-0.01 \\
(0.01)\end{array}$ & $\begin{array}{c}0.00 \\
(0.01)\end{array}$ & $\begin{array}{l}-0.02 \\
(0.09)\end{array}$ \\
\hline $\begin{array}{l}\text { Father's occupation } \\
\text { (government) }\end{array}$ & $\begin{array}{l}0.12^{*} \\
(0.07)\end{array}$ & $\begin{array}{l}-0.00 \\
(0.07)\end{array}$ & $\begin{array}{c}0.08 \\
(0.09)\end{array}$ & $\begin{array}{c}0.07 \\
(0.05)\end{array}$ & $\begin{array}{c}0.11 \\
(0.07)\end{array}$ & $\begin{array}{c}0.01 \\
(0.07)\end{array}$ & $\begin{array}{c}0.07 \\
(0.05)\end{array}$ & $\begin{array}{l}-0.06 \\
(0.06)\end{array}$ & $\begin{array}{l}-0.12 \\
(0.08)\end{array}$ & $\begin{array}{l}-0.05 \\
(0.03)\end{array}$ & $\begin{array}{c}-0.14 * * \\
(0.06)\end{array}$ & $\begin{array}{c}0.37 \\
(0.40)\end{array}$ \\
\hline $\begin{array}{l}\text { Father's occupation } \\
\text { (business) }\end{array}$ & $\begin{array}{l}0.05 \\
(0.07)\end{array}$ & $\begin{array}{l}-0.12 \\
(0.10)\end{array}$ & $\begin{array}{c}0.17 * * * \\
(0.06)\end{array}$ & $\begin{array}{l}-0.02 \\
(0.05)\end{array}$ & $\begin{array}{c}0.05 \\
(0.06)\end{array}$ & $\begin{array}{c}0.02 \\
(0.08)\end{array}$ & $\begin{array}{c}0.07 \\
(0.06)\end{array}$ & $\begin{array}{c}0.08 \\
(0.05)\end{array}$ & $\begin{array}{l}-0.00 \\
(0.05)\end{array}$ & $\begin{array}{l}-0.03 \\
(0.03)\end{array}$ & $\begin{array}{c}-0.15 * * * \\
(0.06)\end{array}$ & $\begin{array}{c}0.06 \\
(0.44)\end{array}$ \\
\hline Mother has job & $\begin{array}{c}0.04 \\
(0.08)\end{array}$ & $\begin{array}{l}-0.04 \\
(0.08)\end{array}$ & $\begin{array}{l}-0.14^{*} \\
(0.08)\end{array}$ & $\begin{array}{l}0.10^{*} \\
(0.06)\end{array}$ & $\begin{array}{c}0.02 \\
(0.08)\end{array}$ & $\begin{array}{c}0.03 \\
(0.10)\end{array}$ & $\begin{array}{c}0.11 \\
(0.10)\end{array}$ & $\begin{array}{l}0.17^{*} \\
(0.09)\end{array}$ & $\begin{array}{l}-0.16 \\
(0.12)\end{array}$ & $\begin{array}{c}0.07 \\
(0.05)\end{array}$ & $\begin{array}{l}-0.17 \\
(0.16)\end{array}$ & $\begin{array}{c}0.11 \\
(0.58)\end{array}$ \\
\hline Constant & $\begin{array}{l}-0.35 \\
(0.30)\end{array}$ & $\begin{array}{c}3.96 * * * \\
(0.52)\end{array}$ & $\begin{array}{c}3.25 * * * \\
(0.45)\end{array}$ & $\begin{array}{c}3.04 * * * \\
(0.33)\end{array}$ & $\begin{array}{c}3.88 * * * \\
(0.31)\end{array}$ & $\begin{array}{c}2.54 * * * \\
(0.42)\end{array}$ & $\begin{array}{c}4.31 * * * \\
(0.28)\end{array}$ & $\begin{array}{l}-0.29 \\
(0.30)\end{array}$ & $\begin{array}{c}1.52 * * * \\
(0.35)\end{array}$ & $\begin{array}{c}0.33 * * \\
(0.17)\end{array}$ & $\begin{array}{c}1.68 * * * \\
(0.41)\end{array}$ & $\begin{array}{l}5.85 * * * \\
(2.19)\end{array}$ \\
\hline Observations & 433 & 433 & 433 & 433 & 433 & 433 & 433 & 433 & 433 & 433 & 433 & 433 \\
\hline R-squared & 0.07 & 0.10 & 0.06 & 0.03 & 0.02 & 0.04 & 0.04 & 0.12 & 0.09 & 0.06 & 0.07 & 0.02 \\
\hline
\end{tabular}

Notes: We clustered the standard error at the survey locations (districts and training center where interviewed were undertaken) and enumerators are reported in parentheses. $* * * \mathrm{p}<0.01, * * \mathrm{p}<0.05, * \mathrm{p}<0.1$. 
Appendix Table 3. Effect of the 2015 pay scale reform on the educational qualifications, market skill, \& personality of BCS officers

\begin{tabular}{|c|c|c|c|c|c|c|c|c|c|}
\hline & $\begin{array}{c}=1 \text { if grade } \\
\text { of SSC exam } \\
\text { is A+ }\end{array}$ & $\begin{array}{c}\text { Engineering } \\
\text { graduate }\end{array}$ & $\begin{array}{c}\text { log real } \\
\text { income in } \\
\text { previous job }\end{array}$ & $\begin{array}{l}\text { Big } 5 \\
\text { index }\end{array}$ & Extraversion & Agreeableness & Conscientiousness & Neuroticism & Openness \\
\hline Post x O & $\begin{array}{l}0.17^{*} \\
(0.09)\end{array}$ & $\begin{array}{c}0.21 * * * \\
(0.06)\end{array}$ & $\begin{array}{l}-0.11 \\
(1.12)\end{array}$ & $\begin{array}{l}-0.02 \\
(0.07)\end{array}$ & $\begin{array}{c}-0.30^{* * *} \\
(0.11)\end{array}$ & $\begin{array}{l}-0.19 \\
(0.14)\end{array}$ & $\begin{array}{l}0.20^{*} \\
(0.12)\end{array}$ & $\begin{array}{c}0.02 \\
(0.20)\end{array}$ & $\begin{array}{l}-0.21 \\
(0.16)\end{array}$ \\
\hline Post & $\begin{array}{c}0.02 \\
(0.08)\end{array}$ & $\begin{array}{l}-0.02 \\
(0.03)\end{array}$ & $\begin{array}{l}-0.74 \\
(1.27)\end{array}$ & $\begin{array}{l}-0.02 \\
(0.04)\end{array}$ & $\begin{array}{c}0.13 \\
(0.08)\end{array}$ & $\begin{array}{c}0.05 \\
(0.16)\end{array}$ & $\begin{array}{l}-0.10 \\
(0.11)\end{array}$ & $\begin{array}{c}0.02 \\
(0.18)\end{array}$ & $\begin{array}{c}0.10 \\
(0.14)\end{array}$ \\
\hline $\mathrm{O}$ & $\begin{array}{c}0.07 \\
(0.05)\end{array}$ & $\begin{array}{c}0.02 \\
(0.04)\end{array}$ & $\begin{array}{c}2.41 * * * \\
(0.91)\end{array}$ & $\begin{array}{c}0.09 \\
(0.08)\end{array}$ & $\begin{array}{c}0.06 \\
(0.11)\end{array}$ & $\begin{array}{c}0.05 \\
(0.09)\end{array}$ & $\begin{array}{l}-0.09 \\
(0.09)\end{array}$ & $\begin{array}{l}-0.01 \\
(0.14)\end{array}$ & $\begin{array}{c}0.11 \\
(0.07)\end{array}$ \\
\hline age & $\begin{array}{l}-0.02 \\
(0.01)\end{array}$ & $\begin{array}{c}0.01 \\
(0.01)\end{array}$ & $\begin{array}{l}0.37^{* *} \\
(0.15)\end{array}$ & $\begin{array}{l}-0.00 \\
(0.01)\end{array}$ & $\begin{array}{l}-0.00 \\
(0.02)\end{array}$ & $\begin{array}{c}0.01 \\
(0.02)\end{array}$ & $\begin{array}{c}0.01 \\
(0.01)\end{array}$ & $\begin{array}{c}0.01 \\
(0.02)\end{array}$ & $\begin{array}{l}-0.01 \\
(0.01)\end{array}$ \\
\hline male & $\begin{array}{l}-0.04 \\
(0.06)\end{array}$ & $\begin{array}{c}0.09 * * * \\
(0.03)\end{array}$ & $\begin{array}{c}1.64 * * * \\
(0.54)\end{array}$ & $\begin{array}{c}0.08^{* *} \\
(0.04)\end{array}$ & $\begin{array}{l}0.13^{*} \\
(0.07)\end{array}$ & $\begin{array}{l}-0.04 \\
(0.09)\end{array}$ & $\begin{array}{l}-0.01 \\
(0.08)\end{array}$ & $\begin{array}{l}-0.12 \\
(0.08)\end{array}$ & $\begin{array}{c}0.07 \\
(0.08)\end{array}$ \\
\hline Raised in urban & $\begin{array}{l}0.12^{* *} \\
(0.06)\end{array}$ & $\begin{array}{c}0.09^{* * * *} \\
(0.03)\end{array}$ & $\begin{array}{c}0.50 \\
(0.59)\end{array}$ & $\begin{array}{l}-0.04 \\
(0.04)\end{array}$ & $\begin{array}{l}-0.14^{*} \\
(0.08)\end{array}$ & $\begin{array}{l}-0.03 \\
(0.08)\end{array}$ & $\begin{array}{c}0.07 \\
(0.05)\end{array}$ & $\begin{array}{l}-0.10 \\
(0.07)\end{array}$ & $\begin{array}{l}-0.07 \\
(0.07)\end{array}$ \\
\hline Father's education & $\begin{array}{l}-0.01 \\
(0.01)\end{array}$ & $\begin{array}{c}0.00 \\
(0.00)\end{array}$ & $\begin{array}{c}0.03 \\
(0.10)\end{array}$ & $\begin{array}{l}-0.01 \\
(0.01)\end{array}$ & $\begin{array}{l}-0.01 \\
(0.01)\end{array}$ & $\begin{array}{l}-0.01 \\
(0.01)\end{array}$ & $\begin{array}{l}-0.02 \\
(0.01)\end{array}$ & $\begin{array}{c}0.00 \\
(0.01)\end{array}$ & $\begin{array}{c}0.01 \\
(0.01)\end{array}$ \\
\hline Mother's education & $\begin{array}{c}0.00 \\
(0.01)\end{array}$ & $\begin{array}{c}0.01 \\
(0.01)\end{array}$ & $\begin{array}{c}0.13 \\
(0.13)\end{array}$ & $\begin{array}{c}0.01 \\
(0.01)\end{array}$ & $\begin{array}{c}0.01 \\
(0.02)\end{array}$ & $\begin{array}{l}0.02 * \\
(0.01)\end{array}$ & $\begin{array}{l}-0.02 \\
(0.02)\end{array}$ & $\begin{array}{c}0.02 \\
(0.01)\end{array}$ & $\begin{array}{l}-0.00 \\
(0.02)\end{array}$ \\
\hline $\begin{array}{l}\text { Father's occupation } \\
\text { (government) }\end{array}$ & $\begin{array}{l}0.07 \\
(0.07)\end{array}$ & $\begin{array}{c}0.04 \\
(0.04)\end{array}$ & $\begin{array}{l}-0.17 \\
(0.86)\end{array}$ & $\begin{array}{l}-0.04 \\
(0.06)\end{array}$ & $\begin{array}{l}0.05 \\
(0.09)\end{array}$ & $\begin{array}{l}-0.00 \\
(0.06)\end{array}$ & $\begin{array}{l}0.08 \\
(0.06)\end{array}$ & $\begin{array}{l}-0.16 \\
(0.14)\end{array}$ & $\begin{array}{l}-0.03 \\
(0.08)\end{array}$ \\
\hline $\begin{array}{l}\text { Father's occupation } \\
\text { (business) }\end{array}$ & $\begin{array}{c}0.06 \\
(0.08)\end{array}$ & $\begin{array}{c}0.02 \\
(0.02)\end{array}$ & $\begin{array}{c}0.40 \\
(0.85)\end{array}$ & $\begin{array}{l}-0.06 \\
(0.05)\end{array}$ & $\begin{array}{l}0.06 \\
(0.12)\end{array}$ & $\begin{array}{l}-0.04 \\
(0.06)\end{array}$ & $\begin{array}{l}-0.07 \\
(0.07)\end{array}$ & $\begin{array}{l}-0.11 \\
(0.12)\end{array}$ & $\begin{array}{l}0.10^{* *} \\
(0.05)\end{array}$ \\
\hline Mother has job & $\begin{array}{l}0.15^{*} \\
(0.09)\end{array}$ & $\begin{array}{l}-0.04 \\
(0.06)\end{array}$ & $\begin{array}{l}-0.86 \\
(0.70)\end{array}$ & $\begin{array}{c}0.02 \\
(0.10)\end{array}$ & $\begin{array}{c}0.10 \\
(0.12)\end{array}$ & $\begin{array}{l}0.20^{*} \\
(0.11)\end{array}$ & $\begin{array}{l}0.21^{*} \\
(0.12)\end{array}$ & $\begin{array}{c}-0.39 * * * \\
(0.12)\end{array}$ & $\begin{array}{c}0.06 \\
(0.12)\end{array}$ \\
\hline Constant & $\begin{array}{l}0.83^{* *} \\
(0.40)\end{array}$ & $\begin{array}{l}-0.34 \\
(0.22)\end{array}$ & $\begin{array}{c}-10.00 * * \\
(4.72)\end{array}$ & $\begin{array}{l}0.05 \\
(0.33)\end{array}$ & $\begin{array}{c}3.84 * * * \\
(0.53)\end{array}$ & $\begin{array}{c}3.65 * * * \\
(0.55)\end{array}$ & $\begin{array}{c}3.53^{* * *} \\
(0.37)\end{array}$ & $\begin{array}{c}2.53^{* * *} \\
(0.61)\end{array}$ & $\begin{array}{c}3.44 * * * \\
(0.40)\end{array}$ \\
\hline Observations & 433 & 433 & 433 & 433 & 433 & 433 & 433 & 433 & 433 \\
\hline R-squared & 0.10 & 0.13 & 0.16 & 0.03 & 0.04 & 0.04 & 0.04 & 0.04 & 0.04 \\
\hline
\end{tabular}

Notes: We clustered the standard error at the survey locations (districts and training center where interviewed were undertaken) and enumerators are reported in parentheses. ${ }^{* * *} \mathrm{p}<0.01,{ }^{* *} \mathrm{p}<0.05, * \mathrm{p}<0.1$. 
Appendix Table 4. Effect of the 2015 pay scale reform on the PSM, pro-social behavior, \& social preferences of BCS officers

\begin{tabular}{|c|c|c|c|c|c|c|c|c|c|c|c|c|}
\hline & $\begin{array}{l}\text { PSM } \\
\text { index }\end{array}$ & $\begin{array}{c}\text { Interested } \\
\text { in Policy } \\
\text { making }\end{array}$ & $\begin{array}{l}\text { Commitment } \\
\text { to pub service }\end{array}$ & $\begin{array}{l}\text { Social } \\
\text { Justice }\end{array}$ & $\begin{array}{l}\text { Civic } \\
\text { duty }\end{array}$ & Compassion & $\begin{array}{c}\text { Self- } \\
\text { sacrifice }\end{array}$ & $\begin{array}{c}=1 \text { if } \\
\text { Participated } \\
\text { voluntary } \\
\text { and } \\
\text { charity } \\
\text { activities }\end{array}$ & $\begin{array}{c}=1 \text { if } \\
\text { Least } \\
\text { Patient }\end{array}$ & $\begin{array}{c}=1 \text { if } \\
\text { Present } \\
\text { Bias }\end{array}$ & $\begin{array}{l}=1 \text { if } \\
\text { Most } \\
\text { risk- } \\
\text { averse }\end{array}$ & $\begin{array}{c}\text { Altruism } \\
\text { to poor } \\
(0-10)\end{array}$ \\
\hline Post x O & $\begin{array}{l}0.26^{* *} \\
(0.10)\end{array}$ & $\begin{array}{c}0.23 \\
(0.16)\end{array}$ & $\begin{array}{c}0.29 * * * \\
(0.11)\end{array}$ & $\begin{array}{l}-0.05 \\
(0.10)\end{array}$ & $\begin{array}{c}0.12 \\
(0.11)\end{array}$ & $\begin{array}{c}0.15 \\
(0.11)\end{array}$ & $\begin{array}{c}0.12 \\
(0.08)\end{array}$ & $\begin{array}{l}-0.07 \\
(0.08)\end{array}$ & $\begin{array}{c}-0.28 * * * \\
(0.09)\end{array}$ & $\begin{array}{c}0.04 \\
(0.05)\end{array}$ & $\begin{array}{c}0.05 \\
(0.11)\end{array}$ & $\begin{array}{c}1.98 * * * \\
(0.67)\end{array}$ \\
\hline Post & $\begin{array}{l}-0.10 \\
(0.09)\end{array}$ & $\begin{array}{l}-0.19 \\
(0.16)\end{array}$ & $\begin{array}{c}0.02 \\
(0.12)\end{array}$ & $\begin{array}{c}0.01 \\
(0.08)\end{array}$ & $\begin{array}{l}-0.06 \\
(0.11)\end{array}$ & $\begin{array}{l}-0.07 \\
(0.08)\end{array}$ & $\begin{array}{l}-0.06 \\
(0.06)\end{array}$ & $\begin{array}{c}0.15 * * \\
(0.06)\end{array}$ & $\begin{array}{c}0.09 * * \\
(0.04)\end{array}$ & $\begin{array}{c}-0.08 * * \\
(0.03)\end{array}$ & $\begin{array}{l}-0.21^{*} \\
(0.11)\end{array}$ & $\begin{array}{c}-1.01^{*} \\
(0.53)\end{array}$ \\
\hline $\mathrm{O}$ & $\begin{array}{c}0.01 \\
(0.07)\end{array}$ & $\begin{array}{l}0.19^{*} \\
(0.11)\end{array}$ & $\begin{array}{l}-0.02 \\
(0.10)\end{array}$ & $\begin{array}{c}0.03 \\
(0.05)\end{array}$ & $\begin{array}{c}-0.11^{* *} \\
(0.05)\end{array}$ & $\begin{array}{l}-0.06 \\
(0.08)\end{array}$ & $\begin{array}{l}-0.00 \\
(0.07)\end{array}$ & $\begin{array}{c}0.00 \\
(0.09)\end{array}$ & $\begin{array}{c}0.01 \\
(0.07)\end{array}$ & $\begin{array}{c}0.05 \\
(0.04)\end{array}$ & $\begin{array}{c}0.07 \\
(0.08)\end{array}$ & $\begin{array}{c}0.52 \\
(0.70)\end{array}$ \\
\hline age & $\begin{array}{l}-0.00 \\
(0.01)\end{array}$ & $\begin{array}{l}-0.02 \\
(0.02)\end{array}$ & $\begin{array}{c}0.01 \\
(0.02)\end{array}$ & $\begin{array}{l}-0.00 \\
(0.01)\end{array}$ & $\begin{array}{c}0.00 \\
(0.01)\end{array}$ & & $\begin{array}{l}-0.01 \\
(0.01)\end{array}$ & $\begin{array}{l}0.02 * * \\
(0.01)\end{array}$ & $\begin{array}{l}-0.01 \\
(0.01)\end{array}$ & $\begin{array}{c}-0.01 * * \\
(0.01)\end{array}$ & $\begin{array}{c}-0.03 * * \\
(0.01)\end{array}$ & $\begin{array}{l}-0.05 \\
(0.08)\end{array}$ \\
\hline male & $\begin{array}{c}0.17 * * * \\
(0.05)\end{array}$ & $\begin{array}{c}0.38 * * * \\
(0.11)\end{array}$ & $\begin{array}{c}0.08 \\
(0.05)\end{array}$ & $\begin{array}{c}0.03 \\
(0.04)\end{array}$ & $\begin{array}{c}0.02 \\
(0.05)\end{array}$ & $\begin{array}{l}-0.03 \\
(0.05)\end{array}$ & $\begin{array}{c}0.05 \\
(0.04)\end{array}$ & $\begin{array}{c}0.35^{* * * *} \\
(0.04)\end{array}$ & $\begin{array}{l}-0.09 \\
(0.07)\end{array}$ & $\begin{array}{l}-0.03 \\
(0.04)\end{array}$ & $\begin{array}{l}-0.03 \\
(0.06)\end{array}$ & $\begin{array}{c}0.13 \\
(0.35)\end{array}$ \\
\hline Raised in urban & $\begin{array}{c}-0.12 * * \\
(0.05)\end{array}$ & $\begin{array}{c}0.00 \\
(0.05)\end{array}$ & $\begin{array}{c}-0.14 * * * \\
(0.05)\end{array}$ & $\begin{array}{c}-0.07 * * \\
(0.03)\end{array}$ & $\begin{array}{c}0.02 \\
(0.08)\end{array}$ & $\begin{array}{l}-0.06 \\
(0.05)\end{array}$ & $\begin{array}{c}-0.11^{* *} \\
(0.04)\end{array}$ & $\begin{array}{l}-0.01 \\
(0.06)\end{array}$ & $\begin{array}{l}-0.08^{*} \\
(0.05)\end{array}$ & $\begin{array}{c}0.00 \\
(0.02)\end{array}$ & $\begin{array}{l}-0.10 \\
(0.07)\end{array}$ & $\begin{array}{c}0.63 * * \\
(0.32)\end{array}$ \\
\hline Father's education & $\begin{array}{l}-0.01 \\
(0.01)\end{array}$ & $\begin{array}{l}-0.01 \\
(0.01)\end{array}$ & $\begin{array}{c}0.01 \\
(0.01)\end{array}$ & $\begin{array}{c}-0.01 * * \\
(0.00)\end{array}$ & $\begin{array}{l}-0.01 \\
(0.01)\end{array}$ & $\begin{array}{l}-0.01 \\
(0.01)\end{array}$ & $\begin{array}{l}-0.00 \\
(0.01)\end{array}$ & $\begin{array}{c}0.00 \\
(0.01)\end{array}$ & $\begin{array}{c}0.00 \\
(0.01)\end{array}$ & $\begin{array}{c}0.01 * * * \\
(0.00)\end{array}$ & $\begin{array}{c}0.01 \\
(0.01)\end{array}$ & $\begin{array}{l}-0.03 \\
(0.05)\end{array}$ \\
\hline Mother's education & $\begin{array}{c}0.00 \\
(0.01)\end{array}$ & $\begin{array}{l}-0.00 \\
(0.01)\end{array}$ & $\begin{array}{l}-0.00 \\
(0.01)\end{array}$ & $\begin{array}{c}0.01 \\
(0.01)\end{array}$ & $\begin{array}{c}0.01 \\
(0.02)\end{array}$ & $\begin{array}{c}0.00 \\
(0.01)\end{array}$ & $\begin{array}{l}-0.00 \\
(0.01)\end{array}$ & $\begin{array}{c}0.00 \\
(0.01)\end{array}$ & $\begin{array}{l}-0.01 \\
(0.01)\end{array}$ & $\begin{array}{l}-0.01 * \\
(0.01)\end{array}$ & $\begin{array}{c}0.00 \\
(0.01)\end{array}$ & $\begin{array}{l}-0.04 \\
(0.10)\end{array}$ \\
\hline $\begin{array}{l}\text { Father's occupation } \\
\text { (government) }\end{array}$ & $\begin{array}{l}0.11 \\
(0.07)\end{array}$ & $\begin{array}{l}-0.02 \\
(0.07)\end{array}$ & $\begin{array}{c}0.08 \\
(0.09)\end{array}$ & $\begin{array}{c}0.07 \\
(0.05)\end{array}$ & $\begin{array}{l}0.11^{*} \\
(0.06)\end{array}$ & $\begin{array}{c}0.01 \\
(0.07)\end{array}$ & $\begin{array}{c}0.07 \\
(0.05)\end{array}$ & $\begin{array}{l}-0.06 \\
(0.06)\end{array}$ & $\begin{array}{l}-0.11 \\
(0.08)\end{array}$ & $\begin{array}{l}-0.05 * \\
(0.03)\end{array}$ & $\begin{array}{c}-0.14 * * \\
(0.06)\end{array}$ & $\begin{array}{c}0.31 \\
(0.42)\end{array}$ \\
\hline $\begin{array}{l}\text { Father's occupation } \\
\text { (business) }\end{array}$ & $\begin{array}{l}0.06 \\
(0.07)\end{array}$ & $\begin{array}{l}-0.11 \\
(0.10)\end{array}$ & $\begin{array}{c}0.18 * * * \\
(0.06)\end{array}$ & $\begin{array}{l}-0.02 \\
(0.05)\end{array}$ & $\begin{array}{l}0.05 \\
(0.06)\end{array}$ & $\begin{array}{c}0.02 \\
(0.08)\end{array}$ & $\begin{array}{c}0.07 \\
(0.06)\end{array}$ & $\begin{array}{c}0.08 \\
(0.05)\end{array}$ & $\begin{array}{l}-0.01 \\
(0.05)\end{array}$ & $\begin{array}{l}-0.02 \\
(0.03)\end{array}$ & $\begin{array}{c}-0.15^{* *} \\
(0.06)\end{array}$ & $\begin{array}{c}0.14 \\
(0.45)\end{array}$ \\
\hline Mother has job & $\begin{array}{c}0.01 \\
(0.09)\end{array}$ & $\begin{array}{l}-0.11 \\
(0.09)\end{array}$ & $\begin{array}{l}-0.16^{*} \\
(0.09)\end{array}$ & $\begin{array}{c}0.10 \\
(0.07)\end{array}$ & $\begin{array}{c}0.04 \\
(0.08)\end{array}$ & $\begin{array}{c}0.03 \\
(0.10)\end{array}$ & $\begin{array}{c}0.10 \\
(0.10)\end{array}$ & $\begin{array}{l}0.18^{*} \\
(0.09)\end{array}$ & $\begin{array}{l}-0.14 \\
(0.12)\end{array}$ & $\begin{array}{l}0.05 \\
(0.04)\end{array}$ & $\begin{array}{l}-0.19 \\
(0.14)\end{array}$ & $\begin{array}{l}-0.22 \\
(0.58)\end{array}$ \\
\hline Constant & $\begin{array}{l}-0.22 \\
(0.29)\end{array}$ & $\begin{array}{l}4.29 * * * \\
(0.51)\end{array}$ & $\begin{array}{l}3.36 * * * \\
(0.45)\end{array}$ & $\begin{array}{l}3.05^{* * * *} \\
(0.35)\end{array}$ & $\begin{array}{l}3.81 * * * \\
(0.33)\end{array}$ & $\begin{array}{l}2.55^{* * * *} \\
(0.43)\end{array}$ & $\begin{array}{c}4.36 * * * \\
(0.29)\end{array}$ & $\begin{array}{l}-0.32 \\
(0.29)\end{array}$ & $\begin{array}{c}1.40^{* * *} \\
(0.38)\end{array}$ & $\begin{array}{c}0.41 * * \\
(0.16)\end{array}$ & $\begin{array}{c}1.78 * * * \\
(0.45)\end{array}$ & $\begin{array}{c}7.39 * * * \\
(2.50)\end{array}$ \\
\hline Obser & 433 & 433 & 433 & 433 & 433 & 433 & 433 & 433 & 433 & 433 & 433 & 433 \\
\hline R-squared & 0.09 & 0.15 & 0.07 & 0.03 & 0.03 & 0.05 & 0.04 & 0.12 & 0.11 & 0.08 & 0.07 & 0.07 \\
\hline
\end{tabular}

Notes: We clustered the standard error at the survey locations (districts and training center where interviewed were undertaken) and enumerators are reported in parentheses. ${ }^{* * *} \mathrm{p}<0.01, * * \mathrm{p}<0.05, * \mathrm{p}<0.1$. 